\title{
Formulation of Improved Traditional Drugs against virulent species of Salmonella spp in Benin: assessment of the properties from Uvaria chamae, Lantana camara and Phyllantus amarus in Benin, West Africa
}

\section{Boris LEGBA}

Research Unit in Applied Microbiology and Pharmacology of natural substances, Research Laboratory in Applied Biology, Polytechnic School of Abomey-Calavi, University of Abomey-Calavi

\section{Victorien DOUGNON ( $\sim$ victorien.dougnon@gmail.com )}

Research Unit in Applied Microbiology and Pharmacology of natural substances, Research Laboratory in Applied Biology, Polytechnic School of Abomey-Calavi, University of Abomey-Calavi https://orcid.org/0000-0001-9047-7299

\section{Carène GBAGUIDI}

Research Unit in Applied Microbiology and Pharmacology of natural substances, Research Laboratory in Applied Biology, Polytechnic School of Abomey-Calavi, University of Abomey-Calavi

\section{Alidah ANIAMBOSSOU}

Research Unit in Applied Microbiology and Pharmacology of natural substances, Research Laboratory in Applied Biology, Polytechnic School of Abomey-Calavi, University of Abomey-Calavi

\section{Esther DEGUENON}

Research Unit in Applied Microbiology and Pharmacology of natural substances, Research Laboratory in Applied Biology, Polytechnic School of Abomey-Calavi, University of Abomey-Calavi

\section{Jacques DOUGNON}

Research Unit in Applied Microbiology and Pharmacology of natural substances, Research Laboratory in Applied Biology, Polytechnic School of Abomey-Calavi, University of Abomey-Calavi

\section{Lamine BABA-MOUSSA}

Laboratory of Biology and Molecular Typing in Microbiology, Faculty of Sciences and Techniques, University of AbomeyCalavi, Benin

\section{Research article}

Keywords: Salmonella Typhimurium ATCC 14028, Public Health, Salmonellosis, Uvaria chamae, Improved Traditional Medicine

Posted Date: December 27th, 2019

DOI: https://doi.org/10.21203/rs.2.16504/v2

License: (c) (i) This work is licensed under a Creative Commons Attribution 4.0 International License. Read Full License

Version of Record: A version of this preprint was published at BMC Veterinary Research on February 10th, 2020. See the published version at https://doi.org/10.1186/s12917-020-2266-1. 


\section{Abstract}

Background Uvaria chamae (Annonaceae), Phyllantus amarus (Phyllantaceae) and Lantana camara (Verbenaceae) are empirically alleged to be used as Beninese medicinal plants in the treatment of salmonellosis. This study aimed to produce scientific data on in vitro and in vivo efficacy of Uvaria chamae, Lantana camara and Phyllantus amarus on multiresistant Salmonella spp isolated in Benin.Results After in vitro tests on aqueous and ethanolic extracts of Uvaria chamae, Lantana camara and Phyllantus amarus, only the aqueous extract of Uvaria chamae (leaves) showed the best anti- Salmonella 's activity. It has been used for the following experiments. The induction of salmonellosis revealed $9.0108 \mathrm{CFU} / \mathrm{ml}$ was optimal concentration for triggering and maintaining the symptoms in chicks. This infective concentration has been used for in vivo assessment. 24 hours post inoculation later, the symptoms of salmonellosis (wet cloaca, diarrhea stool and somnolence) were observed in infected groups. After seven days of treatment, the rate of reduction of bacterial load at 100 $\mathrm{mg} / \mathrm{L}, 200 \mathrm{mg} / \mathrm{L}, 400 \mathrm{mg} / \mathrm{L}$ of this extract was $85 \%, 52.38 \%$ and $98 \%$ respectively in the chicks groups infected with Salmonella Typhimurium ATCC 14028. About the groups infected with Salmonella spp (virulent strain), the rate of reduction of bacterial load at $100 \mathrm{mg} / \mathrm{L}, 200 \mathrm{mg} / \mathrm{L}, 400 \mathrm{mg} / \mathrm{L}$ of this extract was $0 \%, 98.66 \%$ and $99.33 \%$. The toxicity tests did not show any significant effect of the Uvaria chamae 's extract on the biochemical and hematological parameters of the chicks.Conclusion The aqueous extract of Uvaria chamae is active in vitro and in vivo on multiresistant strains of Salmonella spp. This plant is a good candidate for the development of an improved traditional medicine for the management of salmonellosis.

\section{Background}

Salmonella spp is the most common foodborne pathogens habitually isolated from food-producing animals. This germ is responsible for zoonotic infections in humans and animal species including birds. Salmonella spp can be transmitted to humans along the farm-to-fork continuum, commonly through contaminated foods of animal origin, namely poultry and poultry-related products, pork, fish [1].

It is Gram negative, rod-shaped bacteria, and facultative anaerobes belonging to the Enterobacteriaceae's family and divided into three main species: Salmonella enterica, Salmonella bongori and Salmonella subterranean [2]. It is one of the top four causes of diarrheal diseases worldwide [3]. Recent studies estimated that there were approximately 94 million cases of non-typhoid Salmonella gastroenteritis resulting in 155,000 deaths globally each year [4]. Out of these cases, 80.3 million were estimated as foodborne origin [5]. Salmonella Typhimurium, Salmonella Enteritidis, Salmonella Heidelberg and Salmonella Newport are the epidemiologically important serotypes with poultry and have been associated with the majority of human salmonellosis burden worldwide [6-9].

Increasing prevalence of multidrug resistant Salmonella such as resistance towards clinically important antimicrobials like fluoroquinolones and third-generation cephalosporins has become an emerging problem worldwide [10-13]. As an alternative to antimicrobial resistance, exploration of medicinal plants with anti-Salmonella activity is becoming very common in West Africa. In vitro antibacterial activity data of medicinal plant extracts on Salmonella strains do exist [14] but there is a few data about in vivo efficacy of medicinal plants against this bacterium. The difficulty of choosing a suitable study model, the complexity of such research work, and the still limited data on the physiology of Salmonella strains could explain this situation. This study is then devoted to the experimental induction of salmonellosis in chicks as animals' models. These data can be a good starting point for in vivo efficacy testing of herbal extracts on Salmonella spp. Indeed, promoting medicinal plants used in the traditional treatment of salmonellosis involves a structured approach. At this time, an ethnopharmacological survey revealed 57 species of medicinal plants used in the treatment of salmonellosis in Benin [15]. Based on quotation frequency and literary data, Phyllantus amarus, Senna siamea, Uvaria chamae and Lantana camara have been selected. Toxicological, chemical and antibacterial (to ten enteropathogens) characterization have been done. This study showed interesting contents in polyphenols and flavonoids and an effective antibacterial 
activity at $100 \mathrm{mg} / \mathrm{mL}$ with Minimal Inhibitory Concentration (MIC) between 100 and $25 \mathrm{mg} / \mathrm{mL}$ and inhibition diameters between 7.5 and $21 \mathrm{~mm}[16]$.

With these results, it was found necessary to evaluate the in vitro and in vivo efficacy of extracts of Uvaria chamae, Phyllantus amarus and Lantana camara on multiresistant Salmonella spp isolated in Benin.

\section{Results}

\section{In vitro anti-Salmonella activity of Uvaria chamae, Phyllantus amarus and Lantana camara}

Salmonella Typhimurium ATCC 14028 was sensitive to aqueous extract of Uvaria chamae (leaves), ethanolic extract of Phyllantus amarus (leaves), ethanolic and aqueous extract of Lantana camara (leaves). The aqueous extract of Uvaria chamae (leaves) showed the best inhibition diameter $(9.33 \pm 2.08 \mathrm{~mm})$ (Figure 1). There is no significant difference between inhibition diameters $(P \geq 0.05)$ of active extracts.

Figure 2 presents antibacterial activity of aqueous and ethanolic extracts of Uvaria chamae, Phyllantus amarus and Lantana camara on multiresistant strains of Salmonella spp isolated in Benin. Out of ethanolic extract (roots) of Uvaria chamae, all extracts showed variable susceptibility to multiresistant strains of Salmonella spp. Leaves aqueous extract of Uvaria chamae was active on $90 \%$ of Salmonella spp. Root aqueous extract of Uvaria chamae showed the best inhibition diameter (13 $\pm 1 \mathrm{~mm}$ on P19 Salmonella spp). Leaves aqueous extract of Lantana camara and ethanolic leaves extract of Phyllantus amarus showed the smallest inhibition diameters $(6 \mathrm{~mm})$. The MIC, Minimum Bactericidal Concentration (CMB) and the antibiotic potency (ap) of the plant extracts studied on the tested strains are summarized in Table 1. MIC range from 1.625 (Leaves ethanolic extract of Uvaria chamae on P17 Salmonella spp) to $100 \mathrm{mg} / \mathrm{ml}$. Leaves aqueous extract of Uvaria chamae was bacteriostatic on Salmonella Typhimurium ATCC 14028 and Salmonella spp P19.

\section{In vivo anti-Salmonella activity of aqueous extracts (leaves) of Uvaria chamae using chick models}

\section{Preliminary test}

This step aimed to choose the optimal effective concentration of inoculum for Salmonella's induction. 24 hours after infection, wet cloaca and diarrhea stools were detected in groups 1, 2 and 3 infected with $3 \times 108 \mathrm{CFU} / \mathrm{ml}$ (Concentration 1), $6 \times 108 \mathrm{CFU} / \mathrm{ml}$ (Concentration 2), $9 \times 108 \mathrm{CFU} / \mathrm{ml}$ (Concentration 3) respectively whereas these symptoms were absent in group 4, which received distilled water only. These symptoms were present until the 10th day of observation in the group 3 while they disappeared between the fifth and the $7^{\text {th }}$ day in the group 2 (Table 2). However, no deaths were recorded. Salmonella spp was investigated in faecal samples to support clinical observations. The strains were detected in chicks of group 2 and 3, three days after salmonellosis induction. They were present till the ninth day for group 3 whereas they disappeared from feces on the sixth day for group 2 (Table 3). On the ninth day, a bacterial count was made on the faeces samples to assess the bacterial load. The results are shown in Table 4.

Clinical observations suggest that only $9 \times 10^{8} \mathrm{UFC} / \mathrm{ml}$ could trigger and maintain the symptoms of salmonellosis.

\section{In vivo efficacy of leaves aqueous extract of $U$. chamae on Salmonella Typhimurium ATCC 14028 (reference strain) and Salmonella spp P19 (Virulent strain)}

24 hours after induction, symptoms were detected in all infected chicks. Diarrheal stools were abundant. The cloacae of the chicks were wet and somnolence was noticed in some chicks (Tables 5-10). During the 9 days of monitoring, including 7 days of treatment, these symptoms evolved considerably according to the groups. They remained persistent in infected and untreated chicks (group 2). However, diarrhea was slightly reduced at the last days of monitoring, indicating a progression of the disease to asymptomatic carriage (Tables 7 and 8 ). 
Throughout the monitoring, there was a progressive increase in the weight of the chicks of all the groups (figures 3 and 4). For chicks infected by Salmonella Typhimurium ATCC 14028, there was no significant difference in weight change compared to other groups ( $p \geq 0.05$ ) (figure 3). Same observation was done in chicks infected with Salmonella spp P19 (virulent strain) ( $\mathrm{p} \geq 0.05)$ (figure 4).

3 days after infection with Salmonella Typhimurium, the bacterial load of Salmonella increased in all infected chicks, but differentially according to the groups. The bacterial load at day 3 was in the range 2000-30000 CFU/g. Treatment of the chicks with the extracts and colistin started at day 3 and continued until day 9 . During treatment, the bacterial load gradually decreased in group 3 treated with colistin and disappeared on Day 9. In group 2 (infected and untreated), the bacterial load decreased slightly between the third and sixth day (11000 to $10000 \mathrm{CFU} / \mathrm{g}$ ) before undergoing a considerable increase on the ninth day (10000 to $16000 \mathrm{CFU} / \mathrm{g})$. In groups 4, 6 respectively treated with 100 and $400 \mathrm{mg} / \mathrm{l}$ of the extract, the bacterial load was first increased before falling down on day 9 . In group 5 (treated with the extract at $200 \mathrm{mg} / \mathrm{l}$ ), a gradual decline from the $3^{\text {rd }}$ to the $9^{\text {th }}$ day $(21000$ to $10.000 \mathrm{CFU} / \mathrm{g}$ ) (figure 5) was observed. In group 1 (unfected chicks), the bacterial load remained zero.

Bacterial load reduction between the $3^{\text {rd }}$ and the $9^{\text {th }}$ day after the infection ( 7 days of treatment) was assessed globally and summarized in the figure 6 . The inoculum increased by $45.45 \%$ in group 2 (infected and untreated). It was reduced by $100 \%$ in lot 3 (treated with colistin). Treatment with leaves aqueous extract of Uvaria chamae also showed remarkable efficacy (bacterial load reduction between $52.38 \%$ and $98 \%$ ).

3 days after infection with Salmonella spp (virulent strain) (figure 7), the bacterial load of Salmonella increased in all infected chicks. The bacterial load at day 3 was in the range 3000-15000 CFU/g. Treatment of the chicks with the extracts and colistin started on day 3 and continued until day 9 . During treatment, the bacterial load gradually decreased from 1500 to $1000 \mathrm{CFU} / \mathrm{g}$ in group 3 treated with colistin. In group 2 (infected and untreated), the bacterial load decreased slightly between the third and sixth day ( 9000 to $3000 \mathrm{CFU} / \mathrm{g}$ ) before undergoing a considerable increase on the ninth day (3000 to $52,000 \mathrm{CFU} / \mathrm{g}$ ). In groups 4, 6 respectively treated with 100 and $400 \mathrm{mg} / \mathrm{l}$, the bacterial load was first increased before falling on day 9 , whereas in group 5 treated with the extract at $200 \mathrm{mg} / \mathrm{l}$, bacterial load were constant to $15000 \mathrm{CFU} / \mathrm{g}$ between day 3 and day 6 and decreased to $200 \mathrm{CFU} / \mathrm{g}$ at day 9. In group 1 (unfected chicks), the bacterial load remained zero.

Bacterial load reduction between the $3^{\text {rd }}$ and the $9^{\text {th }}$ day after the infection ( 7 days of treatment) was assessed globally and summarized in the figure 8 . The inoculum increased by $477.77 \%$ ( 4.7 times) in group 2 (infected and untreated). It was reduced by $33.33 \%$ in lot 3 (treated with Colistin), 98.66\% in group 5, 99.33\% in group 6. The extract at $100 \mathrm{mg} / \mathrm{I}$ did not allow a reduction of the bacterial load (group 4).

\section{Effects of Leaves aqueous extract of Uvaria chamae on biochemical and hematological parameters}

Effect of Leaves aqueous extract of Uvaria chamae on hematological and biochemical parameters was investigated to evaluate whether as a biologically active substance, this extract did not have a pathological effect on certain biochemical and hematological parameters. The results are shown in Figures 9 and 10.

Uremia increased insignificantly $(\mathrm{p} \geq 0.05)$ at day 4 in chicks which received $400 \mathrm{mg} / \mathrm{l}(4.66 \mathrm{~g} / \mathrm{I}$ to $4.99 \mathrm{~g} / \mathrm{l})$ and $100 \mathrm{mg} / \mathrm{l}$ $(4,49 \mathrm{~g} / \mathrm{I}$ at $5.27 \mathrm{~g} / \mathrm{l})$ of extract. As for those which received $200 \mathrm{mg} / \mathrm{l}$ of extract, their uremia increased at day 7 (4.23g / I to $4.67 \mathrm{~g} / \mathrm{I})$. The creatinine concentration at day 4 increased insignificantly in chicks having $100 \mathrm{mg}$ of extract $(0.17 \mathrm{~g} / \mathrm{I}$ to $0.21 \mathrm{~g} / \mathrm{I})$ and those which received the antibiotic $(0.16 \mathrm{~g} / \mathrm{I}$ to $0.21 \mathrm{~g} / \mathrm{I})$. In chicks which received $200 \mathrm{mg}(0.16 \mathrm{~g} / \mathrm{I}$ to $0.18 \mathrm{~g}$ / I) and $400 \mathrm{mg}(0.17 \mathrm{~g} / \mathrm{I}$ to $0.19 \mathrm{~g} / \mathrm{I})$ of extract, their creatinine increased at day $7(\mathrm{p} \geq 0.05))$. Same observation was done with AST and ALT (no significant variation) (figure 9). With hematological parameters, the same observations are made. There was no significant difference in all groups. However, the number of blood cells increased from the $1^{\text {st }}$ to the 4 th day and from the $4^{\text {th }}$ to the $7^{\text {th }}$ day (figure 10 ). 


\section{Discussion}

This study aimed to produce scientific data on in vitro and in vivo efficacy of extracts of Uvaria chamae, Lantana camara and Phyllantus amarus on multiresistant Salmonella spp isolated in Benin. In vitro anti-Salmonella tests were used to assess the activity of the extracts of the three plants and to select the extract to be used for the in vivo tests.

The performance of the in vivo efficacy test was preceded by an experimental infection which made it possible to choose the optimal concentration of the inoculum.

\section{In vitro anti-Salmonella activity of Uvaria chamae, Phyllantus amarus and Lantana camara}

The aqueous and ethanolic extracts of the leaves and bark of $U$. chamae showed an inhibition of Salmonella spp with the exception of the ethanolic extract of U. chamae's roots. The aqueous extract of Uvaria chamae was active on $90 \%$ of the virulent Salmonella spp and on Salmonella Typhimurium ATCC 14028. These results can be compared to those obtained by Ogueke [17]. This author showed that at a concentration varying between $150-250 \mathrm{mg} / \mathrm{ml}$, aqueous and ethanolic extracts of bark and the ethanolic extract of leaves of Uvaria chamae inhibited Salmonella Typhi.

Aqueous and ethanolic extracts of Phyllantus amarus inhibited Salmonella spp with maximal inhibition diameter of 12 $\mathrm{mm}$. The activity of Phyllantus amarus extracts on Salmonella spp were reported in 2008. Using agar cup diffusion method, the authors showed that ethanolic extracts of $P$. amarus were active on Salmonella Typhi [18]. In our study, only leaves ethanolic extract of Phyllantus amarus inhibit Salmonella Typhimurium ATCC $14028(9.33 \pm 1.53 \mathrm{~mm})$. The inhibitory power of the extract on the reference strain was greater than those obtained in a previous study. For concentrations ranging from 200 to $1000 \mu \mathrm{g} \mathrm{/} \mathrm{ml,} \mathrm{the} \mathrm{inhibition} \mathrm{diameters} \mathrm{varied} \mathrm{between} 7$ and 9 mm on Salmonella Typhimurium ATCC 6539 [19].

The ethanolic leaves extract of Lantana camara had an inhibition diameter of $8 \mathrm{~mm}$ on Salmonella Typhimurium ATCC 14028. The inhibitory power of extracts of Lantana camara on Salmonella spp has already been reported in the literature. Lyumugabe et al. [20] obtained an inhibition diameter of $11 \mathrm{~mm}$ on Salmonella Typhimurium.

\section{Experimental infection of three-day-old chicks with Salmonella Typhimurium ATCC 14028: Preliminary test}

To achieve an experimental infection requires that certain experimental conditions be met. The most important are the virulence of the strain used, the choice of the appropriate study model, the choice of the dose and the optimal infective concentration. The choice of chicks as a study model was motivated by two main reasons.

In this study, we choose three-day old chicks for various reasons. One had to choose an age of susceptibility, an age when the animal's immune system is not mature enough to prevent infection. Such an age guarantees the establishment of the infection. Also it is known that in poultry, the signs of the disease are rarely observed after the first two weeks of life [25]. These strategic choices appear to be optimal since, 24 hours after the infection, the animals showed signs of salmonellosis, particularly in groups 2 and 3, which received the concentrations of inoculum 2 and 3 respectively. It was observed wet cloaca, diarrhea stool and somnolence. Clinical signs have been associated with the detection of salmonella in feces. The chosen model has therefore made it possible to reproduce the disease. Several studies have focused on the use of chicks at an age of susceptibility to optimize infection. Osman et al. (2010) used 1-day-old SPF White Leghorn chicks for inoculation with Salmonella Typhimurium. Beal et al. (2004) confirmed that Salmonella Typhimurium is a nonpathogenic commensal in chickens greater than three days of age and can colonize the tract sub-clinically for 8-9 weeks after experimental infection. However, it is possible to use older birds and have interesting results. It all depends on the nature of the study, the virulence of the strain, the concentration and the infective dose. For example, Pande et al. (2016) used with success henses of 14 weeks for oral induction with S. Typhimurium PT 9. The virulence of Salmonella Typhimurium ATCC 14028 was a guarantee because these virulence factors have been characterized by PCR by Deguenon et al.[27]. This study showed that the strain has 5 virulence genes: invA, spvR, SpvC, FimA and Stn. Spv genes are responsible for the systemic infection and multidrug resistance in humans and animals [28]. SpvC gene is able to inhibit 
the activation of macrophages [29]. Presence of fimA gene indicates the presence of fimbriae which is important for Salmonella spp to adhere to epithelial cells [27]. Stn gene is suspected to contribute to enterotoxigenic potency [30]. The presence of all these genes therefore guarantees the pathogenicity of Salmonella Typhimurium and its ability to infect chicks.

This virulence explains why salmonellosis symptoms were observed in infected animals. Three infective concentrations were chosen because we had no assurance of sufficient bacterial load to induce salmonellosis in chicks of this age. We had to expand the possibilities. The results showed that only concentrations 2 and 3 could trigger the symptoms of salmonellosis. These symptoms were present until the 10th day of observation in the group 3 chicks while they disappeared between the fifth and the 7th day for the group 2. Salmonella spp were investigated in faecal specimens to support clinical observations. Salmonella spp were detected in chicks of group 2 and 3 , three days after infection. Chickens infected with concentration 3 of inoculum still host Salmonella.

By relating microbiological data to clinical observations, it seems obvious that only the infective 3 concentration was able to keep the 3-day-old chicks sicked for 10 days. This observation was reinforced by the count at day 9 . The disappearance of Salmonella in group 2 could be explained by a positive reaction of the immune system of the birds.

\section{In vivo anti-Salmonella activity of Uvaria chamae using chick model}

Leaves aqueous extract of U. chamae inhibit Salmonella Typhimurium ATCC in chicks at 100, 200 and $400 \mathrm{mg} / \mathrm{L}$ but the bacterial load was not canceled. This confirms the in vitro anti-Salmonella tests results which showed that this extract has a bacteriostatic effect on Salmonella Typhimurium ATCC 14028. On the other hand, at 200 and $400 \mathrm{mg} / \mathrm{L}$, the extract showed a better in vivo activity than Colistin on virulent Salmonella spp P19. There is no scientific data on the in vivo activity of extracts of Uvaria chamae on Salmonella spp using chicks model. But interesting data exist about other natural substances. In a last study, Five-months-old local chickens, free of antibodies against fowl typhoid were used for challenge with Salmonella Gallinarum. Administration of extract of Aloe secundiflora showed increase in the levels of interleukin 6 (IL6) [31]. In a recent study, Piper beetle L. leaves extract when used in supplementation in drinking water helped to decrease the colonies of Salmonella sp. in small intestine of quails [32]. Mice model were also used to assess in vivo anti-Salmonella activity of natural substances. Punica granatum extract had significant effects on mortality and the numbers of viable $S$. Typhimurium recovered from feces after experimental infection [33].

The initial decrease in bacterial load of untreated chickens can be explain by the fact that the animals' immune system try to control the infection at first. But in the absence of immunity and specific treatment, bacteria continue to multiply, which increases the bacterial load.

\section{Conclusions}

This study demonstrated the in vitro inhibitory potency of aqueous and ethanolic extracts of Uvaria chamae, Phyllantus amarus and Lantana camara on Salmonella spp. Leaves aqueous extract of U. chamae inhibit Salmonella Typhimurium ATCC 14028 and Salmonella spp in chicks at 200 and $400 \mathrm{mg} / \mathrm{L}$. The extract showed no toxicity at the concentrations tested. This extract could be enhanced by the development of an improved traditional medicine for the management of non-typhoid salmonellosis.

\section{Methods}

Leaves of Lantana camara (Verbenaceae), Leaves and roots of Uvaria chamae (Annonaceae), Leaves of Phyllanthus amarus Schumach.\&.Thonn were collected from the wild. In Benin, no permission was necessary to collect these samples. 
Identification was done at the Beninese National Herbarium (University of Abomey Calavi) by Professor Hounnankpon YEDOMONHAN (https://chercheurs.inrab.org/details/173).

Reference numbers in the Herbarium are AA6686/HNB for Phyllantus amarus, AA6687/HNB for Uvaria chamae, AA6688/HNB for Lantana camara. This experimental research has been done in compliance with our Institution (University of Abomey-Calavi), national and international guidelines. All the plants collected in this study have been replaced by young ones in order to maintain the species survival.

210 three-day old and 90 three-week old Isa Brown male chicks were used for the experimentation. The birds were taken from a commercial hatchery "Terre et Associés", Abomey-Calavi (Benin). The birds were kept in an enclosure carefully cleaned and disinfected. During the experiment, the animals took water and feed. All experiments were conducted according to the protocol approved by Ethical committee of Research Unit of Applied Microbiology and Pharmacology of natural substances. After the procedure, animals were killed in compliance with the Beninese code for the care and use of animals for scientific purposes. All animal restraint for killing was ethically carried out carefully to avoid fear, distress or pain. In order to limit fear, distress or pain related to restraint, ketamine was administered to animals.

Eleven bacterial strains were used:

- Salmonella Typhimurium ATCC 14028 were acquired from Research Unit in Applied Microbiology and Pharmacology of natural substances, University of Abomey-Calavi, Benin.

- Ten multiresistant strains of Salmonella spp: they were isolated by Deguenon et al. [27]. The strains were multidrugresistant to penicillins, first generation cephalosporins and some aminoglycosides.

\section{Production of aqueous and ethanolic extracts}

Method described by Legba et al. (2018) has been used. The organs were dried in the laboratory at a temperature of $16^{\circ} \mathrm{C}$ for. The dried material was then powdered using a Retsch SM 2000/1430 / Upm / Smf type mill. Fifty grams of powder were macerated in $500 \mathrm{ml}$ of distilled water or ethanol on a Stuart Bioblock Scientific Fisher stirrer for 72 hours at room temperature. Homogenate was filtered with hydrophilic cotton and Wattman No. 1 paper. This filtrate was then dried at $40^{\circ}$ $\mathrm{C}$ for ethanolic extract and $50^{\circ} \mathrm{C}$ for aqueous extract in the Pasteur oven.

\section{In vitro anti-Salmonella assessment of aqueous and ethanolic extract of Uvaria chamae, Phyllantus amarus and Lantana camara}

Salmonella Typhimurium 14028 and the ten multiresistant Salmonella spp were used. A 24-hour pure colony of portion from the Mueller Hinton medium of each strain was emulsified in $5 \mathrm{ml}$ of physiological water to give a turbidity of $0.5 \mathrm{Mc}$ Farland [34].

Each inoculum was seeded by swab on Petri dishes containing Mueller Hinton agar. Wells of $6 \mathrm{~mm}$ diameter were hollowed out using sterile Pasteur pipette tip. $50 \mu \mathrm{l}$ of each extract was deposited in the wells. A well containing sterile distilled water served as a negative control. After 1 hour pre-diffusion at room temperature, the petri dish was incubated at $37^{\circ} \mathrm{C}$ in an oven for 24 hours. After incubation period, the dishes were examined for the measurements of the zones of inhibition. [34].

Method used by Legba et al. (2018) were used. $100 \mu \mathrm{l}$ of the stock solution of each extract prepared at $200 \mathrm{mg} / \mathrm{ml}$ were added to $100 \mu \mathrm{l}$ of Mueller-Hinton Broth. A series of two-fold dilution from well to well was made then $100 \mu$ of different bacterial suspensions were added. Positive and negative controls were prepared respectively by adding $100 \mu$ of $\mathrm{MH}$ broth to $100 \mu \mathrm{l}$ of bacterial suspension and $100 \mu \mathrm{l}$ of $\mathrm{MH}$ broth to $100 \mu \mathrm{l}$ of the extracts. The plates were incubated at $37^{\circ} \mathrm{C}$ for 24 hours. The MIC was estimated using Tetrazolium. The content of each well was cultured on Agar MH Agar and incubated at $37^{\circ} \mathrm{C}$ for 24 hours for the determination of $\mathrm{CMB}$. CMB is the lowest concentration of extract to which no colony of bacteria can be observed. The antibiotic potency (a.p) of each extract was then calculated with the formula CMB/CMI. 


\section{Experimental infection of three-day-old Isa Brown male chicks with Salmonella Typhimurium ATCC 14028}

A preliminary microbiological examination of the cloaca of the chicks helped to check if chicks are exempt from Salmonella spp. A cloaca swab was performed on all chicks and Salmonella spp were searched according to the method described by Deguenon et al.[27].

Salmonella inoculums were prepared from a pure isolate of the bacterial strain in distilled water at three selected concentrations: $3 \times 10^{8} \mathrm{CFU}$ (Concentration 1), $6 \times 10^{8} \mathrm{CFU}$ (Concentration 2), $9 \times 10^{8} \mathrm{CFU}$ (Concentration 3).

- Groups $1(\mathrm{n}=3): 2 \mathrm{ml}$ of Inoculum concentration 1

- Groups 2 ( $\mathrm{n}=3): 2 \mathrm{ml}$ of Inoculum concentration 2

- Groups 3 ( $\mathrm{n}=3): 2 \mathrm{ml}$ of Inoculum concentration 3

- Groups $4(\mathrm{n}=3): 2 \mathrm{ml}$ of Distilled water

Oral inoculation was performed using 20-gauge feeding needle and disposal syringe. To confirm the viability of the strain used for inoculation, a sample of each inoculum (about 100 microliters) was taken before and after oral administration for culture at $37^{\circ} \mathrm{C}$ for $24-45$ hours.

The birds were observed for 10 days and the symptoms of salmonellosis were recorded. On days 3, 6, and 9, the feces from each lots of chicks were collected. Salmonella was sought using method described par Deguenon et al.[27]. Five (5) grams of fecal samples were transferred immediately following collection in $45 \mathrm{ml}$ of buffered peptone water. Samples were homogenized in the broth either by vortex mixer and then incubated for $18-24 \mathrm{~h}$ at $37^{\circ} \mathrm{C} .1 \mathrm{ml}$ of pre-enrichment was then inoculated in $9 \mathrm{ml}$ of selenite cystine broth for $24 \mathrm{~h}$. Isolation was done on petri-dishes containing Xylose Lysine Decarboxylase (XLD) and incubated for 24h. API 20E Gallery was used for positive identification of all suspicious colonies from fecal material. Salmonella counts were performed on Day 9 samples to assess bacterial load. The method described by Pande et al. [23].

\section{In vivo anti-salmonella assessment of Leaves aqueous extract of Uvaria chamae}

Salmonella Typhimurium 14028 and Salmonella spp (P19) were used for this step. After inoculation, chicks were treated with leaves aqueous extract of Uvaria chamae and colistin.

For each strain, 90 three-day-old chicks were randomly assorted into six groups:

- Group 1: non-infected and non-treated (G1, $\mathrm{n}=18)$

- Group 2: infected and untreated (G2, $\mathrm{n}=18)$

- Group 3: infected and treated with $200 \mathrm{mg} / \mathrm{l}$ of Colistin (G3, n=18)

- Group 4: infected and treated with $100 \mathrm{mg} / \mathrm{l}$ of Uvaria chamae leaves aqueous extract $(\mathrm{G} 4, \mathrm{n}=18)$

- Group 5: infected and treated with $200 \mathrm{mg} / \mathrm{l}$ of Uvaria chamae leaves aqueous extract $(\mathrm{G} 5, \mathrm{n}=18)$

- Group 6: infected and treated with $400 \mathrm{mg} / \mathrm{l}$ of Uvaria chamae leaves aqueous extract $(\mathrm{G} 6, \mathrm{n}=18)$.

Preliminary examination and inoculation were performed as previously but a single concentration of inoculum were used: $9.010^{8} \mathrm{UFC} / \mathrm{ml}$. The birds were observed for 9 days and the symptoms of salmonellosis were recorded. From the third day after infection, the chicks are subjected to oral treatment with the aqueous leaf extract of Uvaria chamae and colistin as reference antibiotic. The treatment was done for 7 days. On days 3, 6 and 9 after infection, faeces from each group were collected and Salmonella counts were performed [35].

Effects of Leaves aqueous extract of Uvaria chamae on biochemical and hematological parameters 
In order to evaluate the toxicity of Uvaria chamae leaves aqueous extracts for chicks, the different concentrations of extracts tested and Colistin were administered for 7 days to three-week-old chicks.

90 three-week-old Isa Brown male chicks were divided in five groups:

- Group 1: oral administration of $100 \mathrm{mg} / \mathrm{L}$ of Leaves aqueous extract of chamae (G1, $\mathrm{n}=18)$

- Group 2: oral administration of $200 \mathrm{mg} / \mathrm{L}$ of Leaves aqueous extract of chamae $(\mathrm{G} 2, \mathrm{n}=18)$

- Group 3: oral administration of $400 \mathrm{mg} / \mathrm{L}$ of Leaves aqueous extract of chamae $(\mathrm{G} 3, \mathrm{n}=18)$

- Group 4: oral administration of $200 \mathrm{mg} / \mathrm{L}$ of Leaves aqueous extract of chamae $(\mathrm{G} 4, \mathrm{n}=18)$ of Colistin $(\mathrm{G} 4, \mathrm{n}=18)$

- Group 5: water

The hematological (white cell Number (NB); Blood red Cell (NR), Hemoglobin (Hb), Hematocrit (The)) and biochemical (Uremia, creatinine, AST and ALT) data were recorded on Days 0, 4 and 7.

\section{Statistical analysis}

Microbiological data were analyzed using ANOVA test with Graph Pad Prism 7.0 Software. Hematological and Biochemical data were analyzed by the SPSS 17.0 Software.

\section{Abbreviations}

ALT: alanine aminotransferase

ANOVA: Analysis of Variance

a.p: antibiotic potency

API: Analytical Profile Index

AST: aspartate transaminase

ATCC: American Type Culture Collection

CFU: colony forming unit,

G: Group

HNB: National Herbarium of Benin

MIC: Minimum Inhibitory Concentration

MBC: Minimum Bactericidal Concentration

MH: mueller hinton

PCR: Polymerase chain reaction

P9, P70, P16, P14, P15, P19, P362, P368, P17, P29: Salmonella samples identification code

SPF: Specific-Pathogen-Free

SPSS: Statistical Package for the Social Sciences 
ST: Salmonella Typhimurium

TWAS: The World Academy of Sciences

UNESCO: United Nations Educational, Scientific and Cultural Organization

XLD: Xylose Lysine Decarboxylase

\section{Declarations}

\section{Acknowledgements}

Authors are very grateful to M. Arnaud SOHA for his help during the technical protocol.

\section{Authors' contributions:}

$B B L, V D, C G, A A, E D, L B-M$ and JD wrote the protocol.

VD got the funding.

$B B L, V D, C G, A A$, and ED processed laboratory works.

VD did the statistical analyses.

VD, BBL wrote the draft of the manuscript.

VD, JD and LB-M reviewed the manuscript.

All authors have read and approved the manuscript.

\section{Authors' Information}

$\mathrm{BBL}$ is a researcher $(\mathrm{PhD})$ in Microbiology, Biochemistry and Pharmacology of Natural Substances at University of AbomeyCalavi. He focuses on using natural substances to fight antimicrobial resistance. AA and CG work as junior researchers at Research Unit of Applied Microbiology and Pharmacology of natural substances, Polytechnic School of Abomey-Calavi (Benin). They focus on Microbiology and Molecular Biology. They are Master Students in Microbiology. ED works is a researcher $(\mathrm{PhD})$ at Research Unit of Applied Microbiology and Pharmacology of natural substances. She got her PhD degree in Molecular Microbiology and Pharmacology of Natural Substances. She focuses on Salmonella spp. VD is a Senior Lecturer in Microbiologyy at the Polytechnic school of Abomey-Calavi, University of Abomey-Calavi. He is the Project Manager and founding member of the Research Unit in Applied Microbiology and Pharmacology of natural substances, Polytechnic School of Abomey-Calavi, University of Abomey-Calavi, Benin (www.e-urmapha.uac.bj). He got the grant which allowed this research and contributed to knowledge on using medicinal plants for medicinal treatment of salmonellosis in Benin. JD works as a Professor of Pharmacology and Animal Heath at the Department of Animal Health and Production, Polytechnic School of Abomey-Calavi, University of Abomey-Calavi, Benin. He is also Director of Research Unit of Applied Microbiology and Pharmacology of natural sustances at University of Abomey-calavi. LB-M works as Professor of Biochemistry, Microbiology and Molecular Biology at the Faculty of Sciences and Technology, University of Abomey-Calavi, Benin.

\section{Funding}

The authors are very grateful to The World Academy of Sciences (TWAS) and the United Nations Educational, Scientific and Cultural Organization (UNESCO). These two institutions have made this research possible through research funding 
allocated to the research team under the number 487RG/BIO/AF/AC_G-FR3240293303. They have reviewed the research protocol and validated the design of the study and collection, analysis, and interpretation of data. They are also grateful to Benin Centre of Scientific Research and Innovation for their financial support.

\section{Availability of data and material}

All data generated or analysed during this study is included in this published article and supplementary information files.

Ethics approval and consent to participate This study received ethical approval from Ethical committee of Research Unit of Applied Microbiology and Pharmacology of natural substances under the number 035-19/ URMAPHA/ EPAC / UAC.

\section{Consent for publication}

Not applicable

\section{Competiting interests}

Authors declare no competing interest related to this publication.

\section{References}

1. Jajere SM. A review of Salmonella enterica with particular focus on the pathogenicity and virulence factors, host specificity and antimicrobial resistance including multidrug resistance. Vet World. 2019;12:504-21.

2. Bhunia A. Foodborne Microbial Pathogens. New York, NY: Springer New York; 2008. doi:10.1007/978-0-387-74537-4.

3. OMS. Statistiques sanitaires mondiales 2014. 2014.

4. Shannon Majowicz, Musto J, Scallan E, Angulo F, Kirk M, O’Brien S, et al. The global burden of nontyphoidal Salmonella gastroenteritis. - PubMed - NCBI. Clinical Infectious Diseases. 2010;:882-889.

5. Mouttotou N, Ahmad S, Kamran Z, Koutoulis KC. Prevalence, Risks and Antibiotic Resistance of Salmonella in Poultry Production Chain. In: Mares M, editor. Current Topics in Salmonella and Salmonellosis. InTech; 2017. doi:10.5772/67438.

6. Eguale T. Non-typhoidal Salmonella serovars in poultry farms in central Ethiopia: prevalence and antimicrobial resistance. BMC Vet Res. 2018;14:217.

7. Li B, Liu C, Liu L, Li S, Fan N, Hou H, et al. [Prevalence and etiologic agent of Salmonella in livestock and poultry meats in Huai'an City during 2015-2016]. Wei Sheng Yan Jiu. 2018;47:260-300.

8. Adhikari SK, Gyawali A, Shrestha S, Shrestha SP, Prajapati M, Khanal DR. Molecular Confirmation of Salmonella typhimuriumin Poultry from Kathmandu Valley. J Nepal Agric Res Counc. 2018;4:86-9.

9. Fagbamila IO, Barco L, Mancin M, Kwaga J, Ngulukun SS, Zavagnin P, et al. Salmonella serovars and their distribution in Nigerian commercial chicken layer farms. PloS One. 2017;12:e0173097.

10. Iwamoto M, Reynolds J, Karp BE, Tate H, Fedorka-Cray PJ, Plumblee JR, et al. Ceftriaxone-Resistant Nontyphoidal Salmonella from Humans, Retail Meats, and Food Animals in the United States, 1996-2013. Foodborne Pathog Dis. 2017;14:74-83.

11. Elkenany RM, Eladl AH, El-Shafei RA. Genetic characterisation of class 1 integrons among multidrug-resistant Salmonella serotypes in broiler chicken farms. J Glob Antimicrob Resist. 2018;14:202-8.

12. Voss-Rech D, Potter L, Vaz CSL, Pereira DIB, Sangioni LA, Vargas ÁC, et al. Antimicrobial Resistance in Nontyphoidal Salmonella Isolated from Human and Poultry-Related Samples in Brazil: 20-Year Meta-Analysis. Foodborne Pathog Dis. 2017;14:116-24. 
13. Michael GB, Schwarz S. Antimicrobial resistance in zoonotic nontyphoidal Salmonella: an alarming trend? Clin Microbiol Infect. 2016;22:968-74.

14. Boko C. Salmonella enterica dans les mortalités de pintadeaux au Bénin: Etude de terrain, comparaison des souches et activité antibactérienne des extraits de plantes locales. Sciences Vétérinaires. Université de Liège; 2012.

15. Dougnon V, Legba B, Yadouleton A, Agbankpe J, et al. Utilisation des plantes du Sud-Bénin dans le traitement de la fièvre typhoïde:rôle des herboristes. Utilisation des plantes du Sud-Bénin dans le traitement de la fièvre typhoïde: rôle des herboristes. 2018;:11.

16. Lègba $B$, Dougnon V, Ahoyo A, Agbankpè J, Hounmanou G, Aniambossou A, et al. Exploration of the antibacterial and chemical potential of some Beninese pharmacopoiea traditional plants. Microbiol Medica. 2018;32.

doi:10.4081/mm.2017.6998.

17. Ogueke C. The Effects of Ethanolic and Boiling Water Extracts of Rootbarks and leaves of Uvaria chamae on some Hospital Isolates. J Am Sci. 2007;3(3): 68 - 73.:68 - 73.

18. Oluwafemi F, Debiri F. Antimicrobial Effect of Phyllanthus amarus and Parquetina nigrescens on Salmonella typhi. Afr J Biomed Res. 2008;11:215-9.

19. Mazumder A, Mahato A, Mazumder R. Antimicrobial potentiality of Phyllanthus amarus against drug resistant pathogens. Nat Prod Res. 2006;20:323-6.

20. Lyumugabe F, Primitive J, Bayingana C, Bajyana So E. Antimicrobial Activity and Phytochemicals Analysis of Vernonia aemulans, Vernonia amygdalina, Lantana camara and Markhamia lutea Leaves as Natural Beer Preservatives. Am J Food Technol. 2017;12:35-42.

21. Dar M, Ahmad S, Bhat Dr showkat, AHMED R, URWAT U, Mumtaz P, et al. Salmonella typhimurium in poultry: A review. Worlds Poult Sci J. 2017;73:345-54.

22. Aabo S, Christensen JP, Chadfield MS, Carstensen B, Jensen TK, Bisgaard M, et al. Development of an In Vivo Model for Study of Intestinal Invasion by Salmonella enterica in Chickens. Infect Immun. 2000;68:7122-5.

23. Pande VV, Devon RL, Sharma P, McWhorter AR, Chousalkar KK. Study of Salmonella Typhimurium Infection in Laying Hens. Front Microbiol. 2016;7. doi:10.3389/fmicb.2016.00203.

24. Osman K, M I Moussa I, M M Yousef A, M Aly M, Radwan M, Alwathnani H. Pathogenicity of some avian Salmonella serovars in two different animal models: SPF chickens and BALB/c mice. 2010.

25. Elgroud R. Contaminations du poulet de chair par les salmonelles non typhiques en élevages et abattoirs de la wilaya de Constantine: Caractérisations phénotypiques et génotypiques par ERIC-PCR, IS-PCR et PFGE. Thèse pour l'obtention du diplôme de Doctorat en Sciences Vétérinaires. Université Mentouri Constantine; 2009.

26. Beal RK, Wigley P, Powers C, Hulme SD, Barrow PA, Smith AL. Age at primary infection with Salmonella enterica serovar Typhimurium in the chicken influences persistence of infection and subsequent immunity to re-challenge. Vet Immunol Immunopathol. 2004;100:151-64.

27. Deguenon E, Dougnon V, Lozes E, Maman N, Agbankpe J, Abdel-Massih RM, et al. Resistance and virulence determinants of faecal Salmonella spp. isolated from slaughter animals in Benin. BMC Res Notes. 2019;12. doi:10.1186/s13104-019-4341-x.

28. Chiu C-H, Su L-H, Chu C-H, Wang M-H, Yeh C-M, Weill F-X, et al. Detection of multidrug-resistant Salmonella enterica serovar typhimurium phage types DT102, DT104, and U302 by multiplex PCR. J Clin Microbiol. 2006;44:2354-8.

29. Guiney DG, Fierer J. The Role of the spv Genes in Salmonella Pathogenesis. Front Microbiol. 2011;2:129.

30. Nakano M, Yamasaki E, Ichinose A, Shimohata T, Takahashi A, Akada JK, et al. Salmonella enterotoxin (Stn) regulates membrane composition and integrity. Dis Model Mech. 2012;5:515-21.

31. Waihenya R, Mtambo MMA, Nkwengulila G, Minga UM. Efficacy of crude extract of Aloe secundiflora against Salmonella gallinarum in experimentally infected free-range chickens in Tanzania. J Ethnopharmacol. 2002;79:31723.

Page $12 / 26$ 
32. Eka Widjay F, Retnani Y, Hermana W. Evaluation of Piper betle L. Aqueous Extract on Salmonella sp. Isolates from Small Intestine of Quails. Res J Med Plants. 2017;11:62-7.

33. Choi J-G, Kang O-H, Lee Y-S, Chae H-S, Oh Y-C, Brice O-O, et al. In Vitro and In Vivo Antibacterial Activity of Punica granatum Peel Ethanol Extract against Salmonella. Evid Based Complement Alternat Med. 2011;2011:1-8.

34. Société Française de Microbiologie. CASFM / EUCAST: Société Française de Microbiologie. 2017.

35. Pande VV, Devon RL, Sharma P, McWhorter AR, Chousalkar KK. Study of Salmonella Typhimurium Infection in Laying Hens. Front Microbiol. 2016;7. doi:10.3389/fmicb.2016.00203.

\section{Tables}

Table 1 : MIC (mg/ml), MBC (mg/ml) and a. p. of the aqueous and Ethanolic extracts of the plants on Salmonella spp.

\begin{tabular}{|c|c|c|c|c|c|c|c|c|c|c|c|c|}
\hline Extracts & Parameters & $P 9$ & $P 70$ & $P 16$ & $P 14$ & $P 15$ & $P 19$ & $P 362$ & $P 368$ & $P 17$ & $P 29$ & $S T$ \\
\hline U.Chamae & MIC & 12.5 & 25 & 6.25 & 6.25 & 6.25 & 12.5 & - & 12.5 & 3.25 & 12.5 & 6.25 \\
\hline Leaves & MBC & 100 & $>100$ & $>100$ & $>100$ & $>100$ & 100 & - & 50 & 100 & $>100$ & 100 \\
\hline extract & a.p. & 8 & - & - & - & - & 8 & - & 4 & 32 & - & 8 \\
\hline U.Chamae & MIC & 3.125 & - & - & - & - & 3.125 & - & - & 1.5265 & - & - \\
\hline $\begin{array}{l}\text { Leaves } \\
\text { ethanolic }\end{array}$ & MBC & $>100$ & - & - & - & - & $>100$ & - & - & 100 & - & - \\
\hline extract & a.p. & - & - & - & - & - & - & - & - & 65.51 & - & - \\
\hline U.Chamae & MIC & - & - & 50 & - & 6.25 & - & 12.5 & - & - & 25 & - \\
\hline $\begin{array}{c}\text { Roots } \\
\text { aqueous }\end{array}$ & $\mathrm{MBC}$ & - & - & $>100$ & - & $>100$ & - & $>100$ & - & - & $>100$ & - \\
\hline extract & a.p. & - & - & - & - & - & - & - & - & - & - & - \\
\hline U.Chamae & MIB & - & - & - & - & - & - & - & - & - & - & - \\
\hline $\begin{array}{c}\text { Roots } \\
\text { ethanolic }\end{array}$ & $\mathrm{MBC}$ & - & - & - & - & - & - & - & - & - & - & - \\
\hline extract & a.p. & - & - & - & - & - & - & - & - & - & - & - \\
\hline P. amarus & MIC & - & - & 50 & - & - & - & 100 & - & - & 50 & - \\
\hline $\begin{array}{l}\text { Leaves } \\
\text { aqueous }\end{array}$ & MBC & - & - & $>100$ & - & - & - & $>100$ & - & - & $>100$ & - \\
\hline extract & a.p. & - & - & - & - & - & - & - & - & - & - & - \\
\hline P.amarus & MIC & 6.25 & - & - & 25 & - & - & - & - & - & 12.5 & 12.5 \\
\hline $\begin{array}{c}\text { Leaves } \\
\text { ethanolic }\end{array}$ & MBC & $>100$ & - & - & $>100$ & - & - & - & - & - & $>100$ & $>100$ \\
\hline extract & a.p. & - & - & - & - & - & - & - & - & - & - & - \\
\hline L.camara & MIB & - & - & - & - & - & - & - & - & - & - & - \\
\hline $\begin{array}{l}\text { Leaves } \\
\text { aqueous }\end{array}$ & MBC & - & - & - & - & - & - & - & - & - & - & - \\
\hline extract & a.p. & - & - & - & - & - & - & - & - & - & - & - \\
\hline L.camara & MIB & & 6.25 & & & 3.125 & & & & & 12.5 & 12.5 \\
\hline $\begin{array}{l}\text { Leaves } \\
\text { ethanolic }\end{array}$ & MBC & & $>100$ & & & $>100$ & & & & & $>100$ & $>100$ \\
\hline extract & a.p. & - & - & - & - & - & - & - & - & - & - & - \\
\hline
\end{tabular}


Table 2 : Salmonellosis Symptoms in three-day-old chicks inoculated with Salmonella Typhimurim ATCC 14028(n $=3$ for each concentration of inoculum)

\begin{tabular}{|c|c|c|c|c|c|c|c|c|c|c|c|}
\hline \multirow[t]{2}{*}{ Groups } & \multirow[t]{2}{*}{ Salmonellosis symptoms } & \multicolumn{10}{|c|}{ Days Post infection } \\
\hline & & 1 & 2 & 3 & 4 & 5 & 6 & 7 & 8 & 9 & 10 \\
\hline \multirow{3}{*}{$\left(3.010^{8} \mathrm{UFC} / \mathrm{ml}\right)$} & Wet cloacal & - & - & - & - & - & - & - & - & - & - \\
\hline & diarrheal stool & + & - & - & - & - & - & - & - & - & - \\
\hline & Somnolence & - & - & - & - & - & - & - & - & - & - \\
\hline \multirow{3}{*}{$\begin{array}{c}2 \\
\left(6.010^{8} \mathrm{UFC} / \mathrm{ml}\right)\end{array}$} & Wet cloacal & + & + & + & + & + & - & - & - & - & - \\
\hline & diarrheal stool & + & + & + & + & + & + & + & - & - & - \\
\hline & Somnolence & - & + & - & - & - & - & - & - & - & - \\
\hline \multirow{3}{*}{$\begin{array}{c}3 \\
\left(9.010^{8} \mathrm{UFC} / \mathrm{ml}\right)\end{array}$} & Wet cloacal & + & + & + & + & + & + & + & + & + & + \\
\hline & diarrheal stool & + & + & + & + & + & + & + & + & + & + \\
\hline & Somnolence & - & - & + & + & - & - & - & - & - & - \\
\hline \multirow{3}{*}{$\begin{array}{c}4 \\
\text { (Distilled Water) }\end{array}$} & Wet cloacal & - & - & - & - & - & - & - & - & - & - \\
\hline & diarrheal stool & - & - & - & - & - & - & - & - & - & - \\
\hline & Somnolence & - & - & - & - & - & - & - & - & - & - \\
\hline
\end{tabular}

Legend: Absence (-), Presence (+)

Table 3 : Salmonella detection in fecal samples of three-day-old chicks inoculated with Salmonella Typhimurim ATCC 14028( $\mathrm{n}=3$ for each concentration of inoculum)

\begin{tabular}{ccccc}
\hline Groups & \multicolumn{4}{l}{ Detection of Salmonella at Days Post infection } \\
\cline { 2 - 5 } & 0 & 3 & 6 & 9 \\
\hline $\mathrm{G} 1$ & - & - & - & - \\
$\left(3.010^{8} \mathrm{UFC} / \mathrm{mI}\right)$ & & & & - \\
\hline $\mathrm{G} 2$ & - & + & - & + \\
$\left(6.010^{8} \mathrm{UFC} / \mathrm{m}\right)$ & & & & \\
\hline $\mathrm{G} 3$ & - & + & + & - \\
$\left(9.010^{8} \mathrm{UFC} / \mathrm{ml}\right)$ & & & & + \\
\hline $\mathrm{G} 4$ & - & - & - & \\
\hline
\end{tabular}

Legend: Absence (-), Presence (+)

Table 4 : Salmonella count in fecal samples of three-day-old chicks inoculated with Salmonella Typhimurim ATCC 14028 


\begin{tabular}{cc}
\hline Groups & Bacterial load at Day 9 (CFU/g) \\
& \\
\hline G1 $\left(3.010^{8} \mathrm{UFC} / \mathrm{m}\right)$ & 0 \\
\hline $\mathrm{G} 2\left(6.010^{8} \mathrm{UFC} / \mathrm{m}\right)$ & 0 \\
\hline $\mathrm{G} 3\left(9.010^{8} \mathrm{UFC} / \mathrm{m}\right)$ & $1.67 .10^{3}$ \\
\hline G4(Distilled Water) & 0 \\
\hline
\end{tabular}

Table 5 : Salmonellosis Symptoms in three-day-old chicks inoculated with Salmonella Typhimurim ATCC 14028 and treated with Leaves aqueous extract of U.Chamae and Colistin ( $\mathrm{n}=18$ for each group)

\begin{tabular}{|c|c|c|c|c|c|c|c|c|c|c|}
\hline \multirow[t]{2}{*}{ Groups } & \multirow{2}{*}{$\begin{array}{l}\text { Salmonellosis } \\
\text { symptoms }\end{array}$} & \multicolumn{9}{|c|}{ Days Post infection } \\
\hline & & 1 & 2 & 3 & 4 & 5 & 6 & 7 & 8 & 9 \\
\hline \multirow{3}{*}{$\begin{array}{c}\text { G1 } \\
\text { (non-infected and non-treated) }\end{array}$} & Wet cloacal & - & - & - & $\overline{-}$ & - & - & - & - & - \\
\hline & diarrheal stool & - & - & - & - & - & - & - & - & - \\
\hline & Somnolence & - & - & - & - & - & - & - & - & - \\
\hline \multirow{3}{*}{$\begin{array}{c}\mathbf{G 2} \\
\text { (infected and untreated) }\end{array}$} & Wet cloacal & + & + & + & + & + & + & + & + & + \\
\hline & diarrheal stool & + & + & + & + & + & + & + & + & + \\
\hline & Somnolence & - & + & + & + & + & + & - & - & - \\
\hline \multirow{3}{*}{$\begin{array}{c}\text { G3 } \\
\text { (Infected and treated with } 200 \mathrm{mg} / \mathrm{l} \text { of Colistin) }\end{array}$} & Wet cloacal & + & + & + & + & + & - & - & - & - \\
\hline & diarrheal stool & + & + & + & + & + & + & - & - & - \\
\hline & Somnolence & + & + & + & - & - & - & - & - & - \\
\hline \multirow{3}{*}{$\begin{array}{c}\text { G4 } \\
\text { (infected and treated with } 100 \mathrm{mg} / \mathrm{l} \text { of Uvaria chamae leaves aqueous } \\
\text { extract) }\end{array}$} & Wet cloacal & + & + & + & + & + & + & - & - & - \\
\hline & diarrheal stool & + & + & + & + & + & + & + & + & - \\
\hline & Somnolence & + & + & + & - & - & - & - & - & - \\
\hline \multirow{3}{*}{$\begin{array}{c}\text { G5 } \\
\text { (infected and treated with } 200 \mathrm{mg} / \mathrm{l} \text { of Uvaria chamae leaves aqueous } \\
\text { extract) }\end{array}$} & Wet cloacal & + & + & + & + & + & + & + & - & - \\
\hline & diarrheal stool & + & + & + & + & + & + & - & - & - \\
\hline & Somnolence & + & + & - & - & - & - & - & - & - \\
\hline \multirow{3}{*}{$\begin{array}{c}\text { G6 } \\
\text { (infected and treated with } 400 \mathrm{mg} / \mathrm{l} \text { of Uvaria chamae leaves aqueous } \\
\text { extract) }\end{array}$} & Wet cloacal & + & + & + & + & + & + & - & - & - \\
\hline & diarrheal stool & + & + & + & + & + & + & + & - & - \\
\hline & Somnolence & + & + & + & + & - & - & - & - & - \\
\hline
\end{tabular}

Table 6 : Salmonellosis Symptoms in three-day-old chicks inoculated with P19 Salmonella spp strain and treated with Leaves aqueous extract of U.Chamae and Colistin ( $\mathrm{n}=18$ for each group) 


\begin{tabular}{|c|c|c|c|c|c|c|c|c|c|c|}
\hline \multirow[t]{2}{*}{ Groups } & \multirow{2}{*}{$\begin{array}{l}\text { Salmonellosis } \\
\text { symptoms }\end{array}$} & \multicolumn{9}{|c|}{ Days Post infection } \\
\hline & & 1 & 2 & 3 & 4 & 5 & 6 & 7 & 8 & 9 \\
\hline \multirow{3}{*}{$\begin{array}{c}\text { G1 } \\
\text { (non-infected and non-treated) }\end{array}$} & Wet cloacal & - & - & - & - & - & - & - & - & - \\
\hline & diarrheal stool & - & - & - & - & - & - & - & - & - \\
\hline & Somnolence & - & - & - & - & - & - & - & - & - \\
\hline \multirow{3}{*}{$\begin{array}{c}\text { G2 } \\
\text { (infected and untreated) }\end{array}$} & Wet cloacal & + & + & + & + & + & + & + & + & + \\
\hline & diarrheal stool & + & + & + & + & + & + & + & + & + \\
\hline & Somnolence & + & + & + & + & - & - & - & - & - \\
\hline \multirow{3}{*}{$\begin{array}{c}\text { G3 } \\
\text { (Infected and treated with } 200 \mathrm{mg} / \mathrm{l} \text { of Colistin) }\end{array}$} & Wet cloacal & + & + & + & + & + & + & - & - & - \\
\hline & diarrheal stool & + & + & + & + & + & + & - & - & - \\
\hline & Somnolence & + & + & + & + & - & - & - & - & - \\
\hline \multirow{3}{*}{$\begin{array}{c}\text { G4 } \\
\text { (infected and treated with } 100 \mathrm{mg} / \mathrm{l} \text { of Uvaria chamae leaves aqueous } \\
\text { extract) }\end{array}$} & Wet cloacal & + & + & + & + & + & + & + & - & - \\
\hline & diarrheal stool & + & + & + & + & + & + & + & + & + \\
\hline & Somnolence & + & + & + & - & - & - & - & - & - \\
\hline \multirow{3}{*}{$\begin{array}{c}\text { G5 } \\
\text { (infected and treated with } 200 \mathrm{mg} / \mathrm{l} \text { of Uvaria chamae leaves aqueous } \\
\text { extract) }\end{array}$} & Wet cloacal & + & + & + & + & - & - & - & - & - \\
\hline & diarrheal stool & + & + & + & + & + & + & - & - & - \\
\hline & Somnolence & + & + & + & - & - & - & - & - & - \\
\hline \multirow{3}{*}{$\begin{array}{c}\text { G6 } \\
\text { (infected and treated with } 400 \mathrm{mg} / \mathrm{l} \text { of Uvaria chamae leaves aqueous } \\
\text { extract) }\end{array}$} & Wet cloacal & 3 & - & - & - & - & - & - & - & - \\
\hline & diarrheal stool & + & + & + & + & + & + & - & - & - \\
\hline & Somnolence & + & + & - & - & - & - & - & - & - \\
\hline
\end{tabular}

Legend: Absence (-), Presence (+) 
Table 7: Evolution of faeces aspect from three-day-old chicks inoculated with Salmonella Typhimurim ATCC 14028 and treated with Leaves aqueous extract of Uh Chamae and Colistin

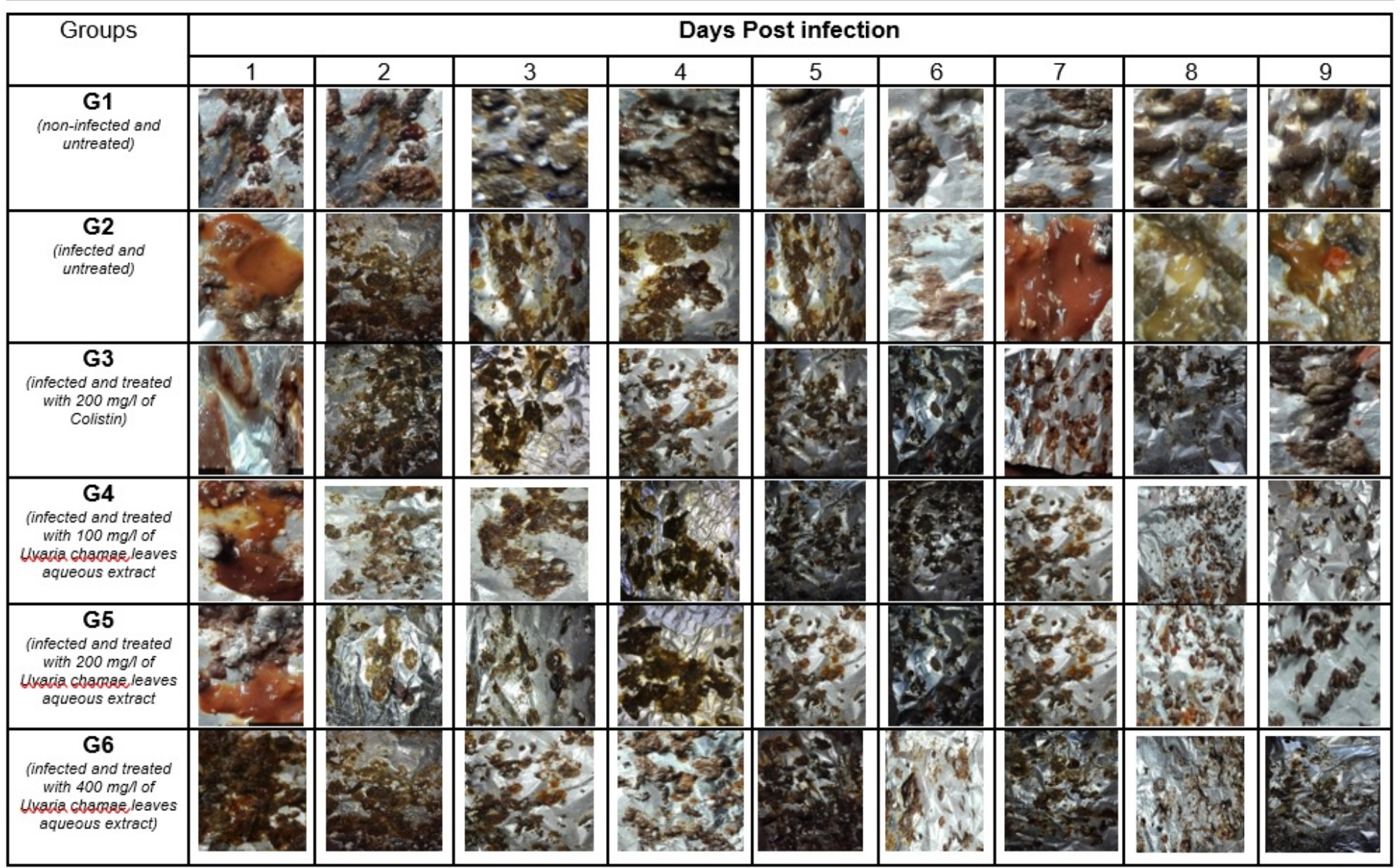


Table 8: Evolution of faeces aspect from three-day-old chicks inoculated with P19 Salmonella strain and treated with Leaves aqueous extract of U Chamae and Colistin

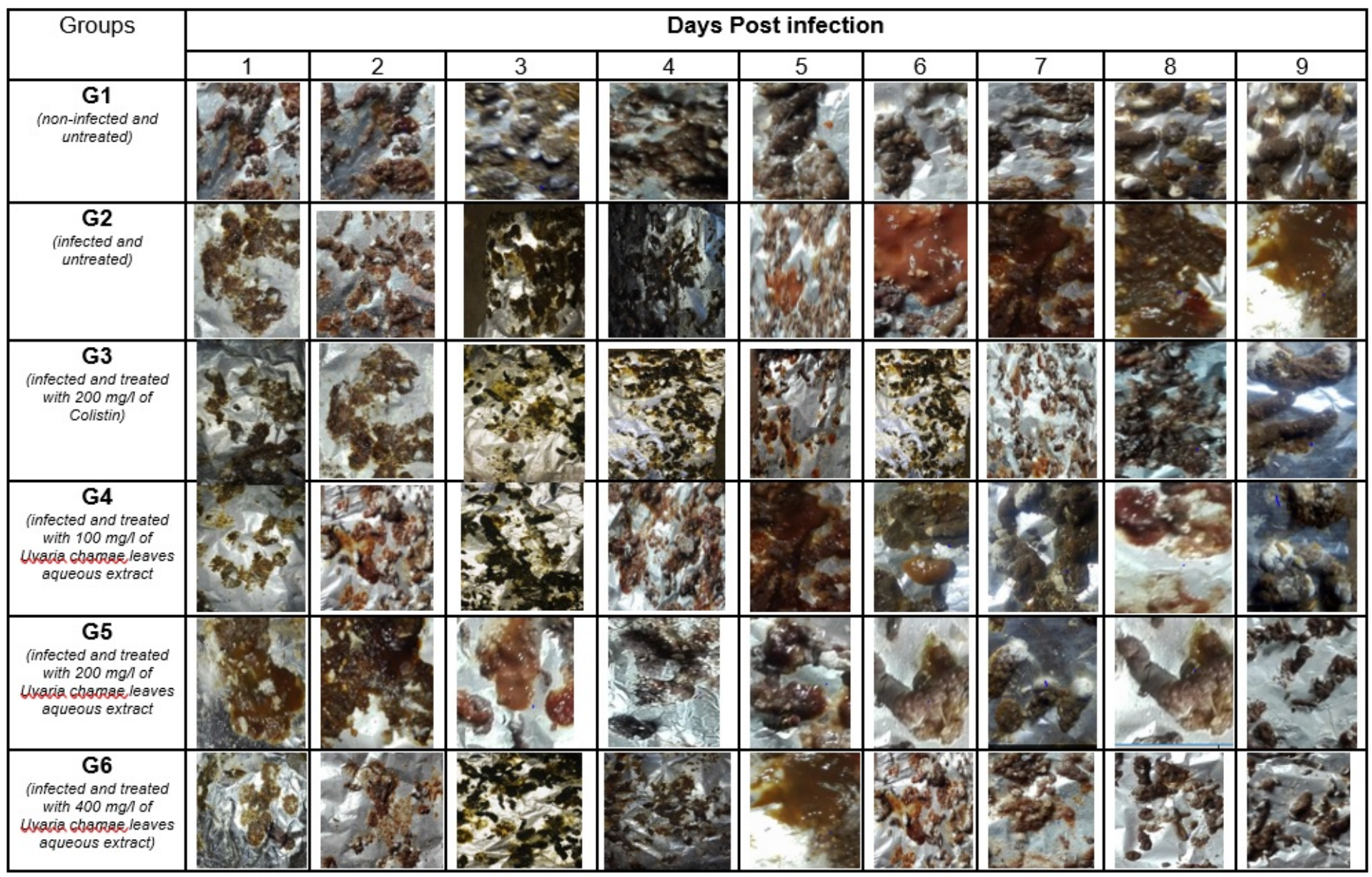


Table 9: Evolution of cloacal aspect from three-day-old chicks inoculated with Salmonella Typhimurium and treated with Leaves aqueous extract of U Chamae and Colistin

\begin{tabular}{|c|c|c|c|c|c|c|c|c|c|}
\hline \multirow[t]{2}{*}{ Groups } & \multicolumn{9}{|c|}{ Days Post infection } \\
\hline & 1 & 2 & 3 & 4 & 5 & 6 & 7 & 8 & 9 \\
\hline $\begin{array}{c}\mathbf{G 1} \\
\text { (non-infected and } \\
\text { untreated) }\end{array}$ & & & & & & & & & \\
\hline $\begin{array}{c}\mathbf{G 2} \\
\text { (infected and } \\
\text { untreated) }\end{array}$ & & & & & & & & & \\
\hline $\begin{array}{c}\text { G3 } \\
\text { (infected and treated } \\
\text { with } 200 \mathrm{mgh} \text { of } \\
\text { Colistin) }\end{array}$ & & & & & & & & & \\
\hline $\begin{array}{c}\mathbf{G 4} \\
\text { (infected and treated } \\
\text { with } 100 \mathrm{mgh} \text { of } \\
\text { Wkgriq chospaeleaves } \\
\text { aqueous extract }\end{array}$ & & & & & & & & & \\
\hline $\begin{array}{c}\text { G5 } \\
\text { (infected and treated } \\
\text { with } 200 \mathrm{mg} / \text { of } \\
\text { Wkgriq chorgaeleaves } \\
\text { aqueous extract }\end{array}$ & & & & & & & & & \\
\hline $\begin{array}{c}\mathbf{G 6} \\
\text { (infected and treated } \\
\text { with } 400 \mathrm{mgh} \text { of } \\
\text { Ukaria chomareleaves } \\
\text { aqueous extract) }\end{array}$ & & & & & & & & & \\
\hline
\end{tabular}


Table 10: Evolution of cloacal aspect from three-day-old chicks inoculated with P19 Salmonella and treated with Leaves aqueous extract of U Chamae and Colistin

\begin{tabular}{|c|c|c|c|c|c|c|c|c|c|}
\hline \multirow[t]{2}{*}{ Groups } & \multicolumn{9}{|c|}{ Days Post infection } \\
\hline & 1 & 2 & 3 & 4 & 5 & 6 & 7 & 8 & 9 \\
\hline $\begin{array}{c}\mathbf{G 1} \\
\begin{array}{c}\text { (non-infected and } \\
\text { untreated) }\end{array}\end{array}$ & & & & & & & & & \\
\hline $\begin{array}{c}\mathbf{G 2} \\
\text { (infected and } \\
\text { untreated) }\end{array}$ & & & & & & & & & \\
\hline $\begin{array}{c}\text { G3 } \\
\text { (infected and treated } \\
\text { with } 200 \mathrm{mg} / \text { of } \\
\text { Colistin) }\end{array}$ & & & & & & & & & \\
\hline $\begin{array}{c}\mathbf{G 4} \\
\text { (infected and treated } \\
\text { with } 100 \mathrm{mg} / \text { of } \\
\text { Uxaria sbomaeleaves } \\
\text { aqueous extract }\end{array}$ & & & & & & & & & \\
\hline $\begin{array}{c}\text { G5 } \\
\text { (infected and treated } \\
\text { with } 200 \mathrm{mg} / \text { of } \\
\text { Uxabia sbomaeleaves } \\
\text { aqueous extract }\end{array}$ & & & & & & & & & \\
\hline $\begin{array}{c}\mathbf{G 6} \\
\text { (infected and treated } \\
\text { with } 400 \mathrm{mg} / \text { of } \\
\text { Uxariq cbograe leaves } \\
\text { aqueous extract) }\end{array}$ & & & & & & & & & \\
\hline
\end{tabular}

\section{Figures}



Aqueous Extract

Ethanolic Extract

Figure 1 
Antibacterial activity of aqueous and ethanolic extracts of Uvaria chamae, Phyllantus amarus and Lantana camara on Salmonella Typhimurium ATCC 14028
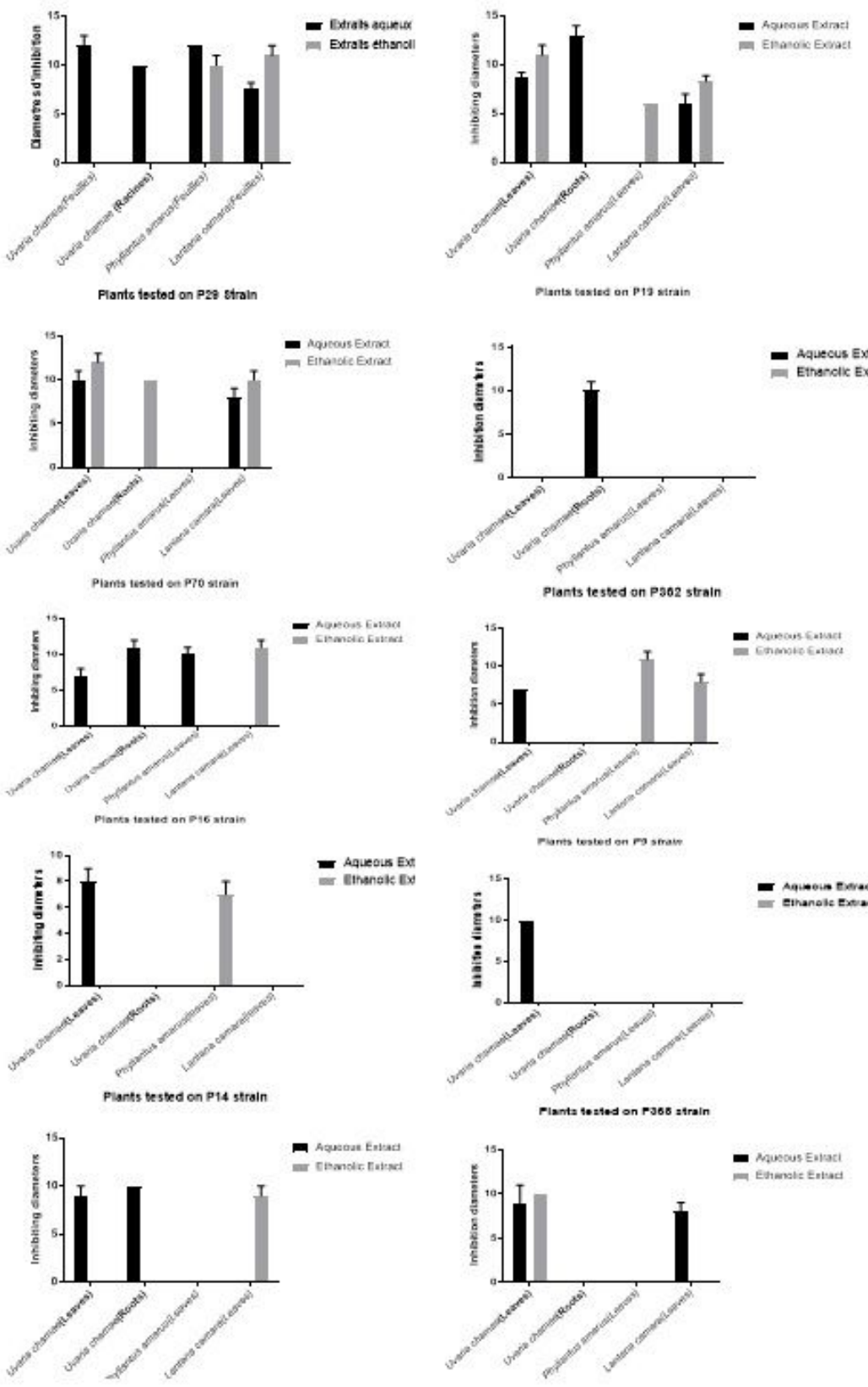

Figure 2

Antibacterial activity of aqueous and ethanolic extracts of Uvaria chamae, Phyllantus amarus and Lantana camara on multiresistant Salmonella spp isolated in Benin 


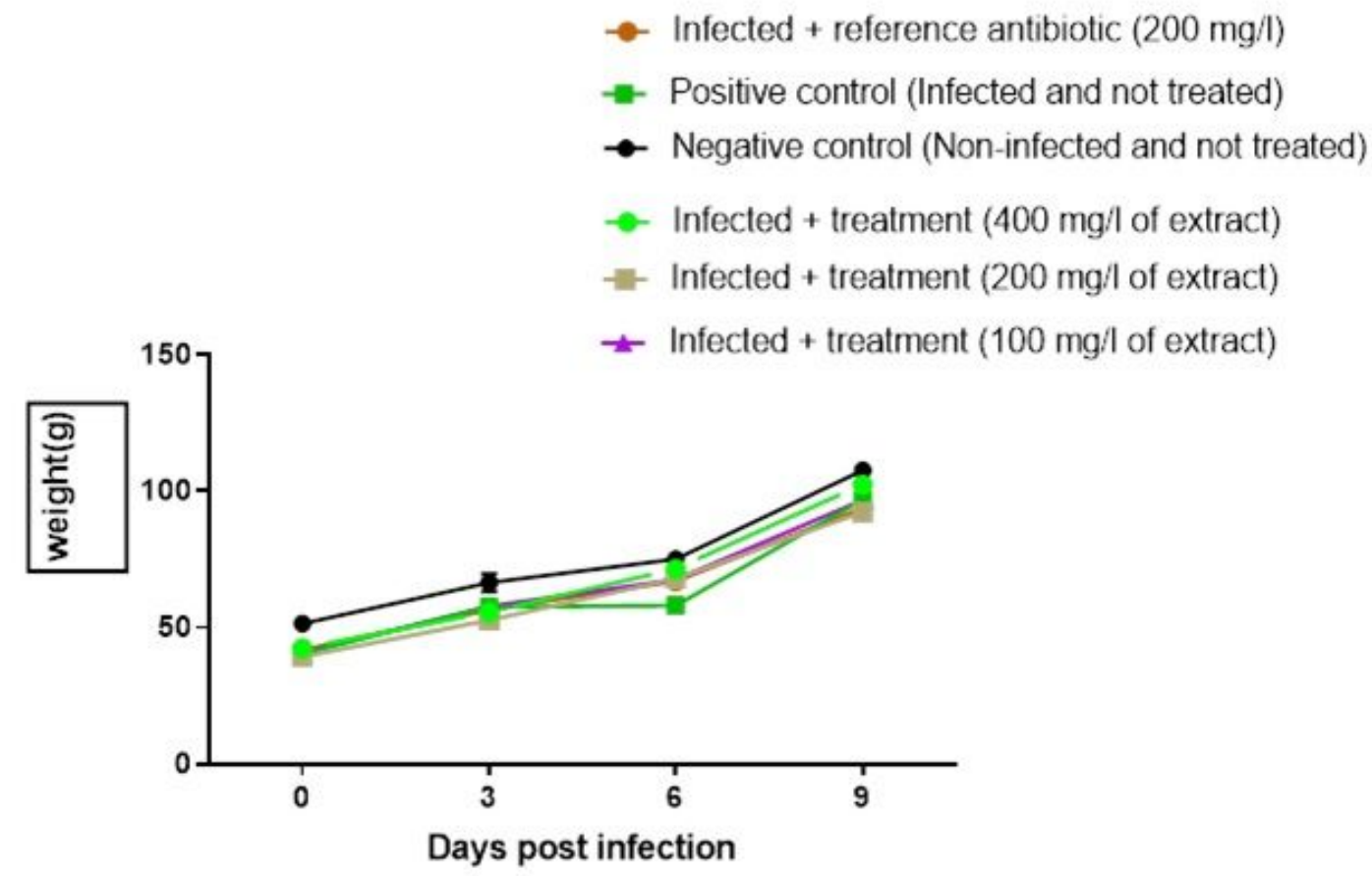

Figure 3

weight changes of chicks orally infected with Salmonella Typhimurium 14028 and treated with leaves aqueous extract of U.chamae and Colistin

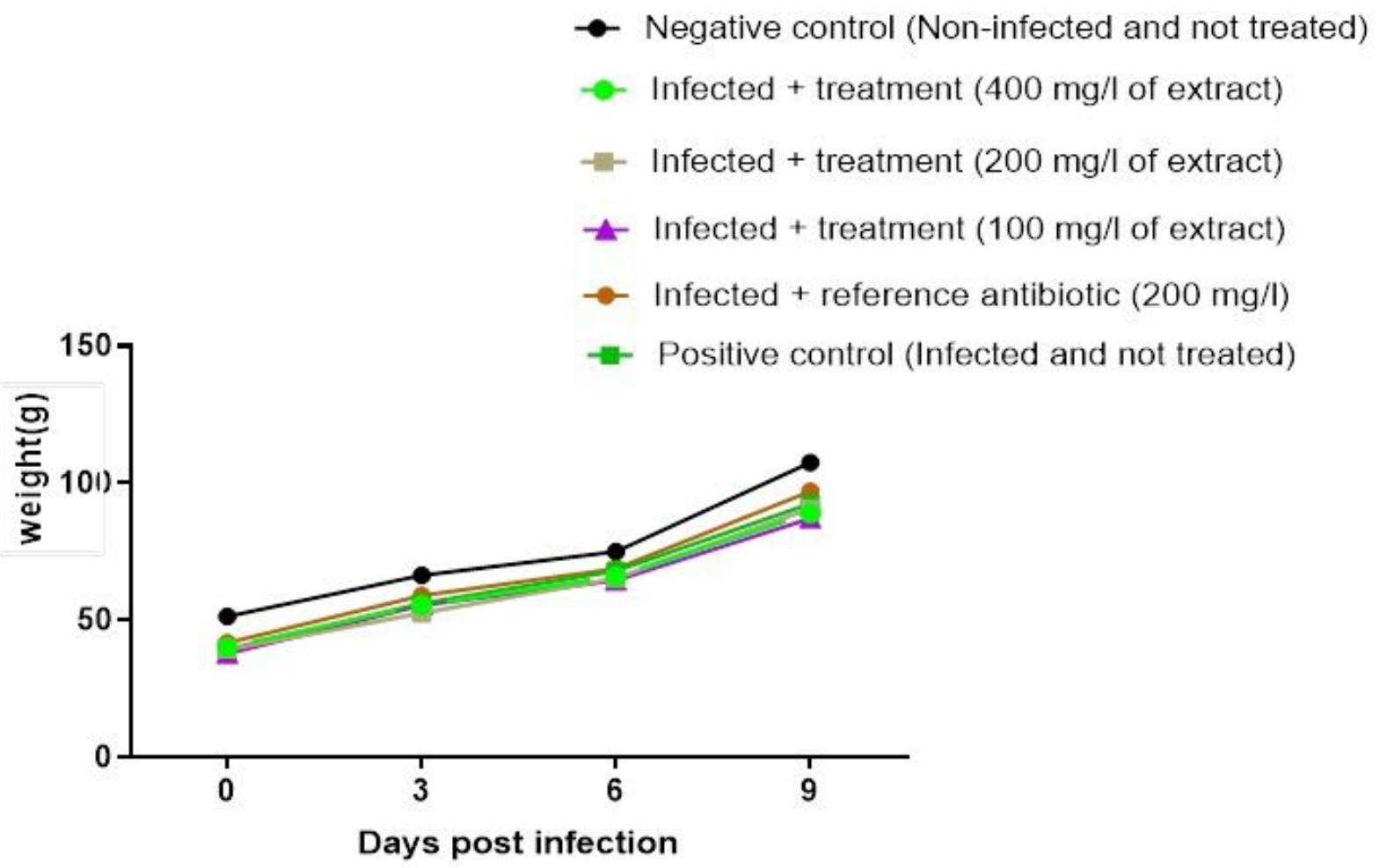

\section{Figure 4}

Weight changes of chicks orally infected with Salmonella spp (P19) and treated with leaves aqueous extract of U.chamae and Colistin 


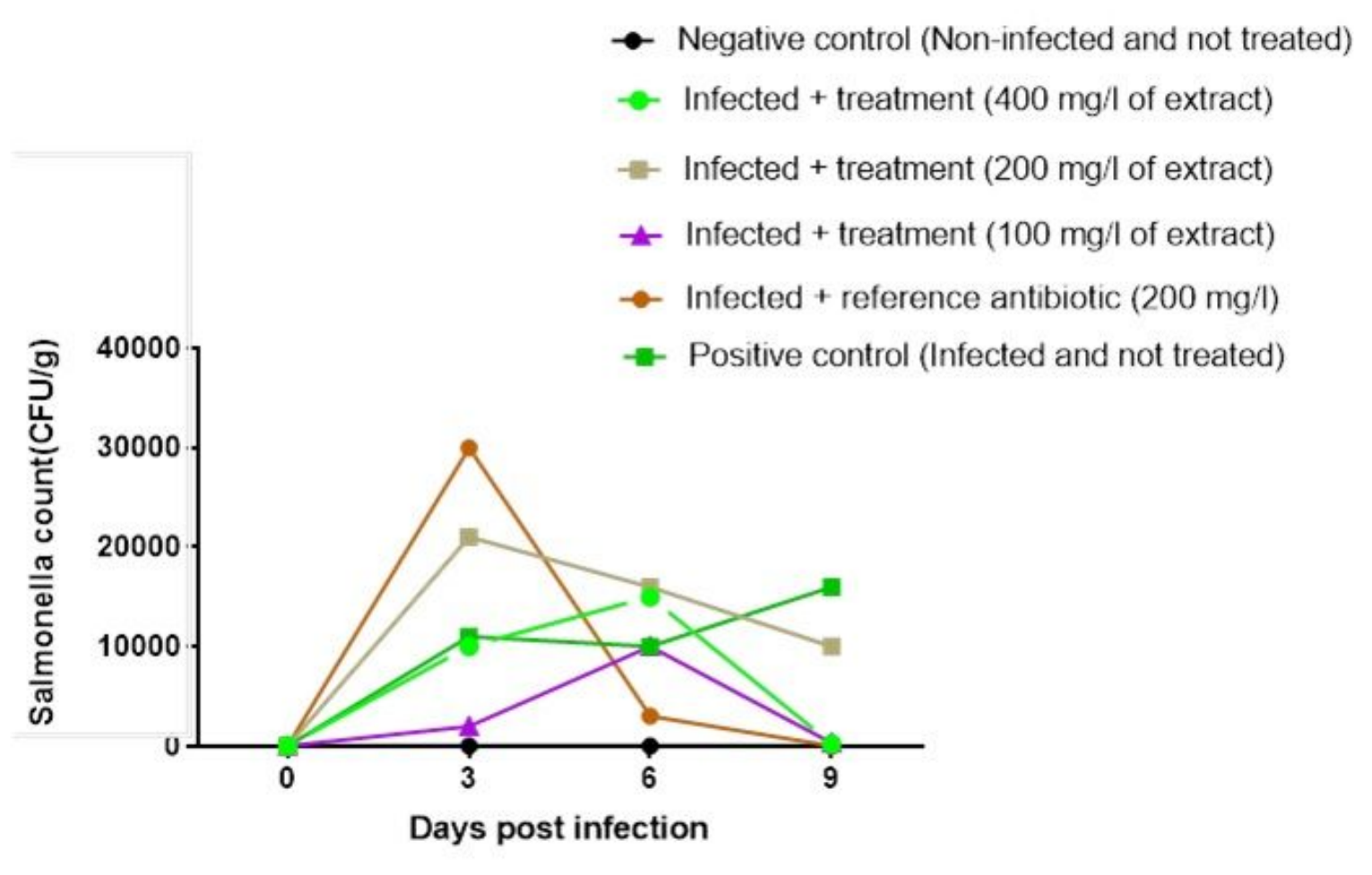

Figure 5

Enumeration of Salmonella from feces of chicks orally infected with S. Typhimurium 14028 and treated with leaves aqueous extract of U.chamae and Colistin

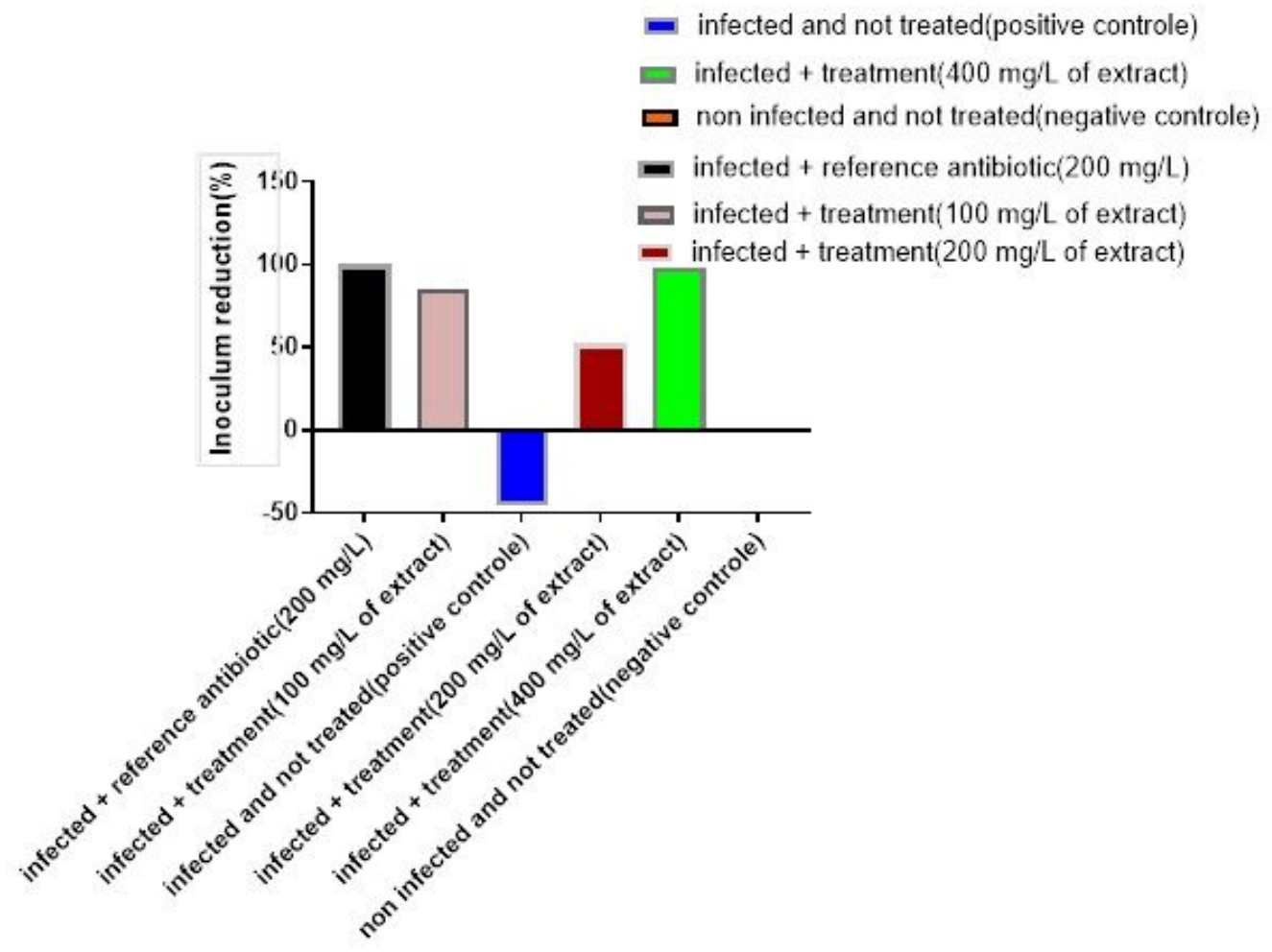

Figure 6

Inoculum reduction of Salmonella Typhimurium 14028 between Day 3 and Day 9(Seven-day treatment) 


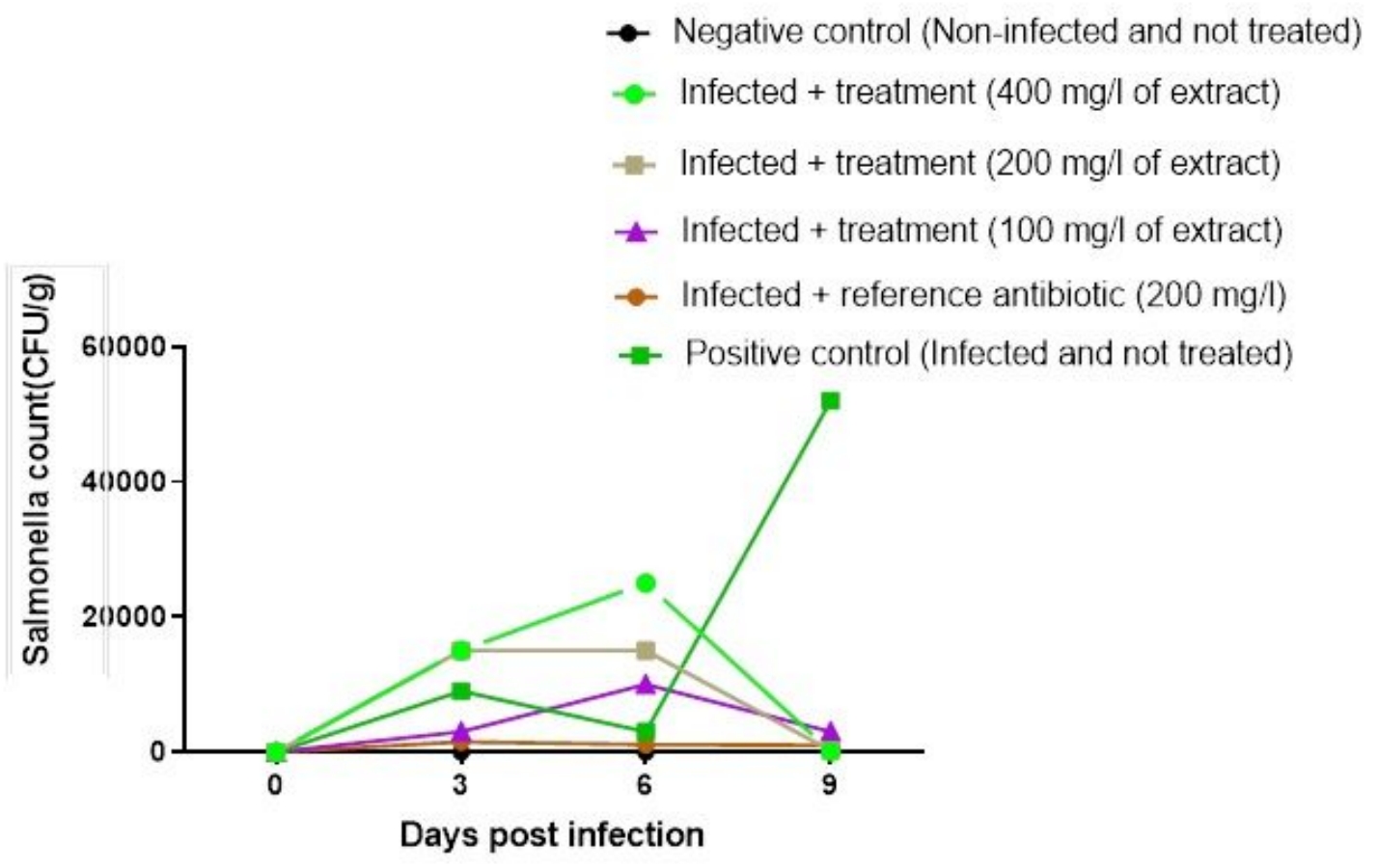

Figure 7

Enumeration of Salmonella from faeces of chicks orally infected with Salmonella spp (P19) and treated with leaves aqueous extract of U.chamae and Colistin

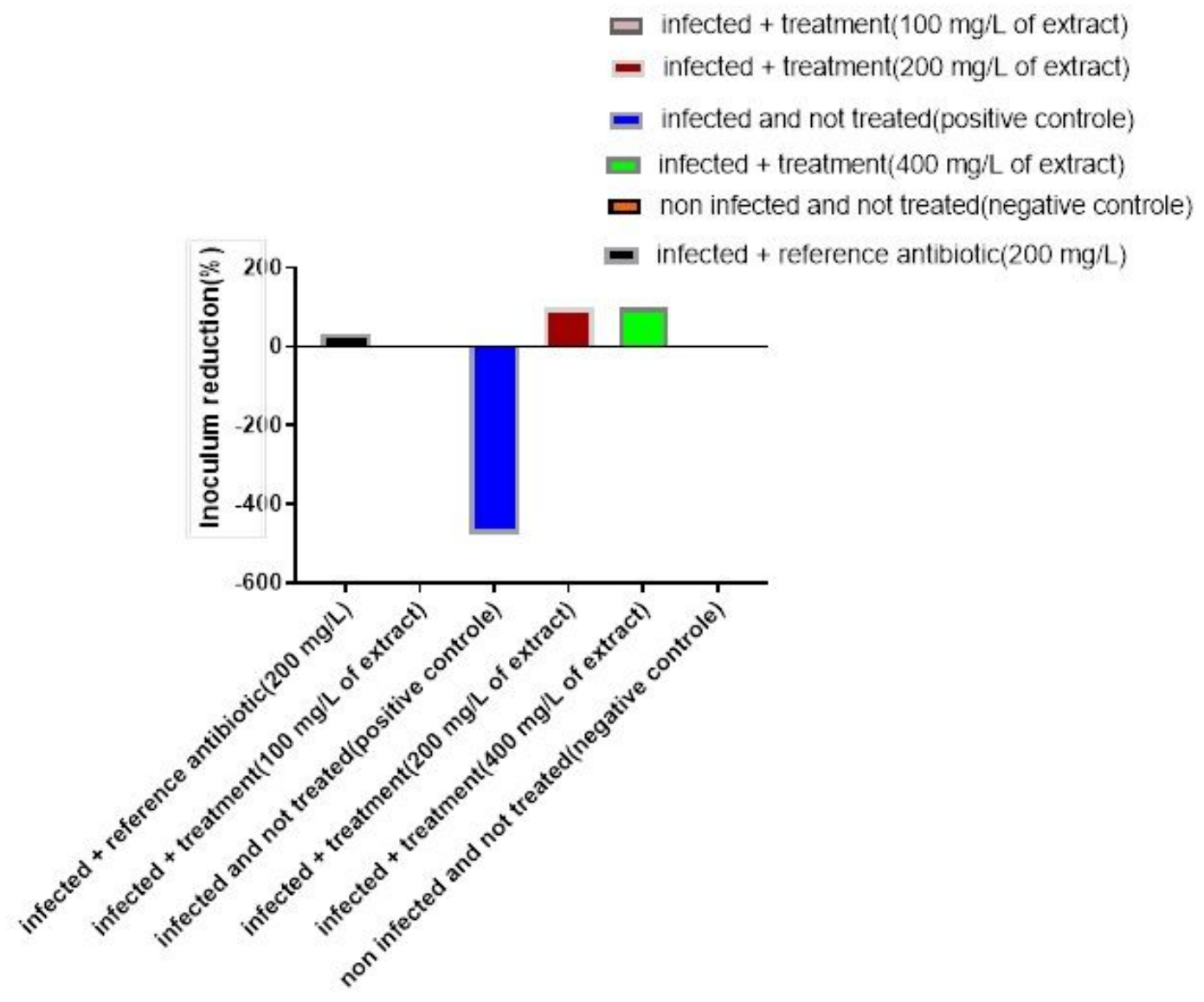

Figure 8 
Inoculum reduction of Salmonella spp (P19) between Day 3 and Day 9(Seven-day treatment)
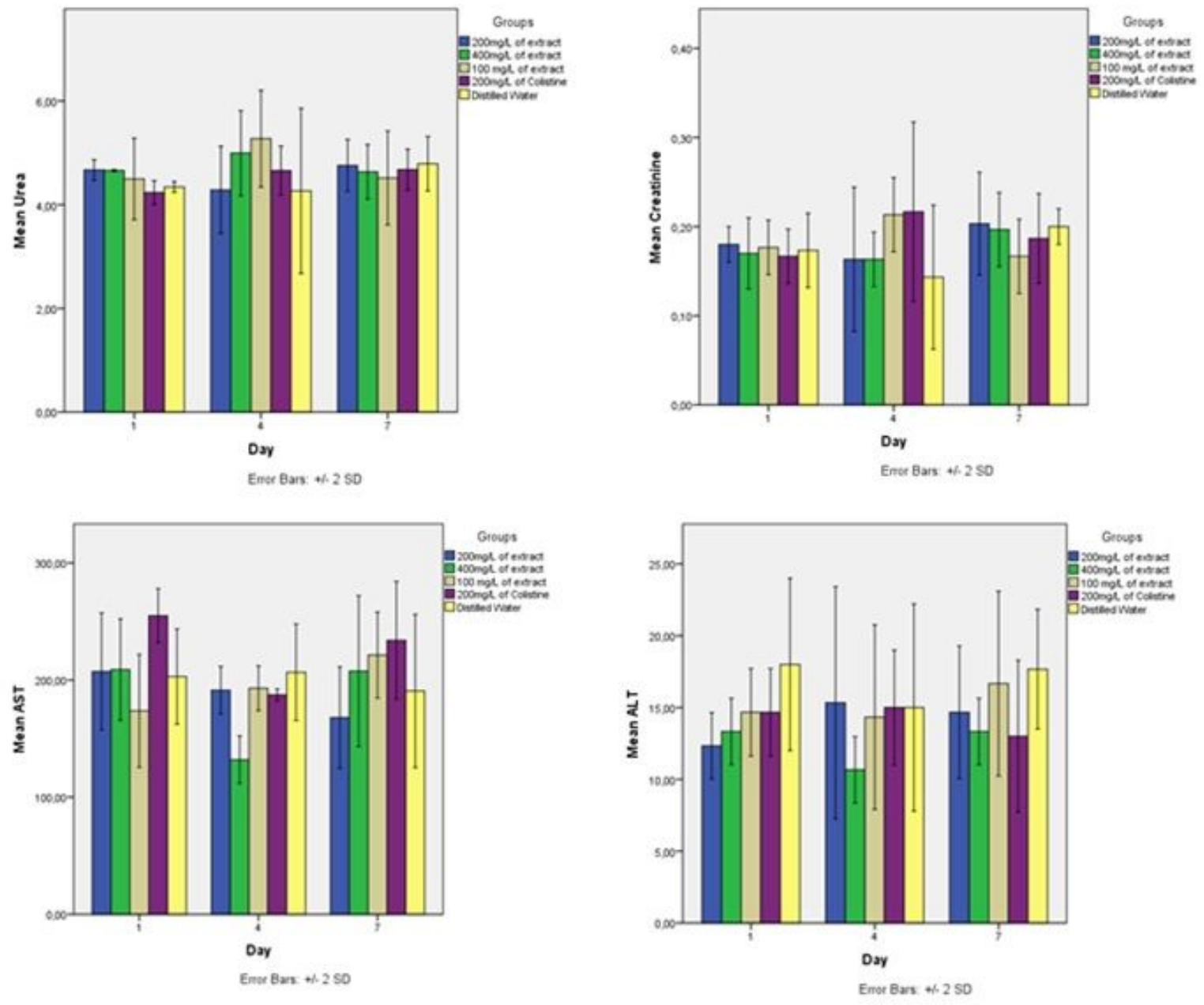

Figure 9

Effect of Leaves aqueous extract of Uvaria chamae on Biochemical parameters of Three-week-old chicks 

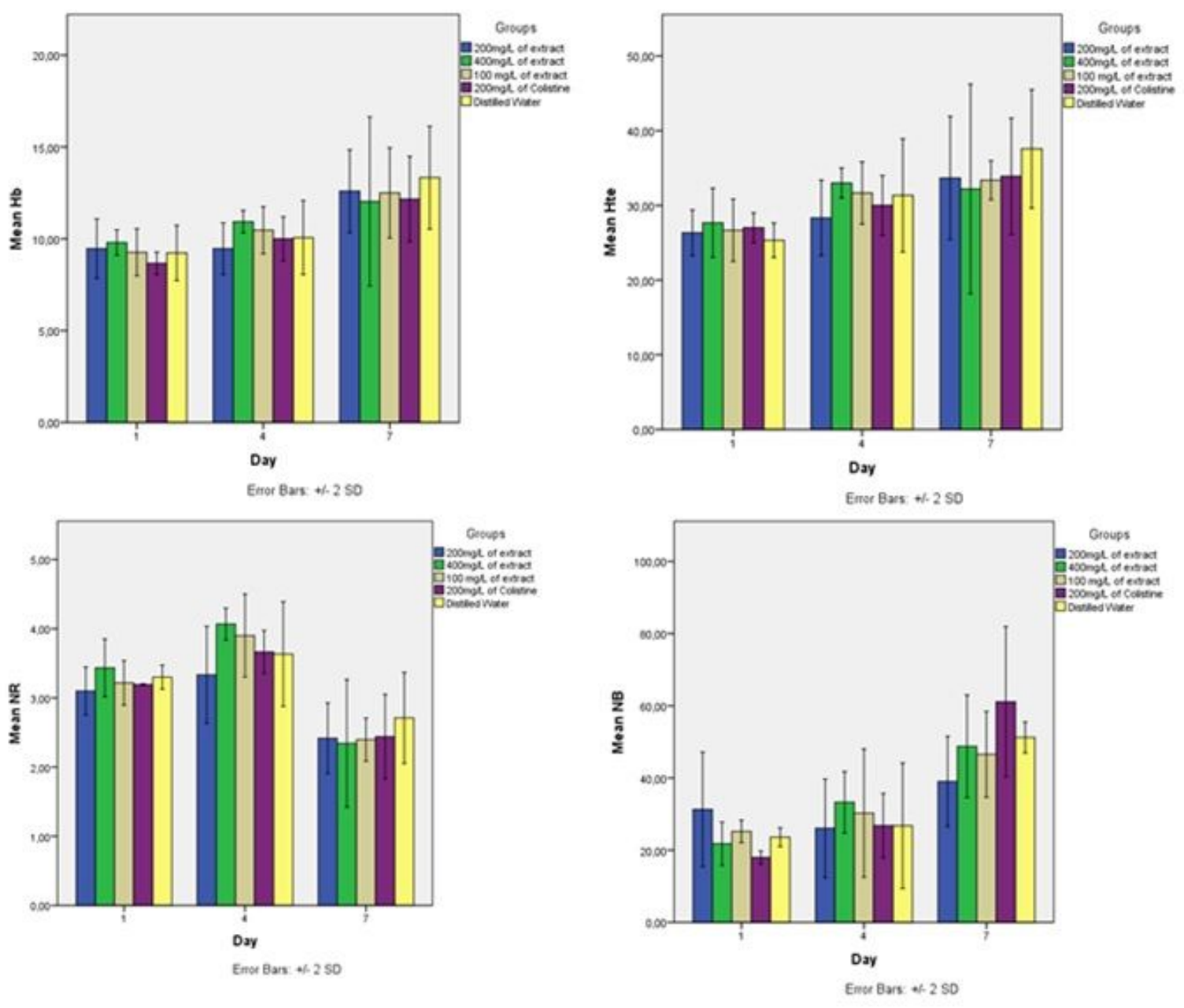

Figure 10

Effect of Leaves aqueous extract of Uvaria chamae on Haematological parameters of Three-week-old chicks

\section{Supplementary Files}

This is a list of supplementary files associated with this preprint. Click to download.

- NC3RsARRIVEGuidelinesChecklistfillablecompleted.pdf 